\title{
Response of methane emissions from wetlands to the Last Glacial Maximum and an idealized Dansgaard-Oeschger climate event: insights from two models of different complexity
}

\author{
B. Ringeval ${ }^{1,2,3,{ }^{*} \text {, P. O. Hopcroft }}{ }^{1}$, P. J. Valdes ${ }^{1}$, P. Ciais ${ }^{3}$, G. Ramstein ${ }^{3}$, A. J. Dolman ${ }^{2}$, and M. Kageyama ${ }^{3}$ \\ ${ }^{1}$ Bristol Research Initiative for the Dynamic Global Environment (BRIDGE), School of Geographical Sciences, \\ University of Bristol, Bristol, BS8 1SS, UK \\ ${ }^{2}$ VU University Amsterdam, Department of Earth Sciences, Boelelaan 1085, 1081 HV Amsterdam, The Netherlands \\ ${ }^{3}$ Laboratoire des Sciences du Climat et de L'Environnement, CEA/CNRS/UVSQ - UMR8212, CEA Saclay - Orme des \\ Merisiers, 91191 Gif-sur-Yvette, France \\ *now at: Institute for Marine and Atmospheric Research Utrecht (IMAU), Utrecht, The Netherlands
}

Correspondence to: B. Ringeval (b.ringeval@ sron.nl)

Received: 17 July 2012 - Published in Clim. Past Discuss.: 1 August 2012

Revised: 24 November 2012 - Accepted: 20 December 2012 - Published: 23 January 2013

\begin{abstract}
The role of different sources and sinks of $\mathrm{CH}_{4}$ in changes in atmospheric methane $\left(\left[\mathrm{CH}_{4}\right]\right)$ concentration during the last $100000 \mathrm{yr}$ is still not fully understood. In particular, the magnitude of the change in wetland $\mathrm{CH}_{4}$ emissions at the Last Glacial Maximum (LGM) relative to the pre-industrial period (PI), as well as during abrupt climatic warming or Dansgaard-Oeschger (D-O) events of the last glacial period, is largely unconstrained. In the present study, we aim to understand the uncertainties related to the parameterization of the wetland $\mathrm{CH}_{4}$ emission models relevant to these time periods by using two wetland models of different complexity (SDGVM and ORCHIDEE). These models have been forced by identical climate fields from low-resolution coupled atmosphere-ocean general circulation model (FAMOUS) simulations of these time periods. Both emission models simulate a large decrease in emissions during LGM in comparison to PI consistent with ice core observations and previous modelling studies. The global reduction is much larger in ORCHIDEE than in SDGVM (respectively -67 and $-46 \%$ ), and whilst the differences can be partially explained by different model sensitivities to temperature, the major reason for spatial differences between the models is the inclusion of freezing of soil water in ORCHIDEE and the resultant impact on methanogenesis substrate availability in boreal regions. Besides, a sensitivity test performed with ORCHIDEE in which the methanogenesis substrate
\end{abstract}

sensitivity to the precipitations is modified to be more realistic gives a LGM reduction of $-36 \%$. The range of the global LGM decrease is still prone to uncertainty, and here we underline its sensitivity to different process parameterizations. Over the course of an idealized D-O warming, the magnitude of the change in wetland $\mathrm{CH}_{4}$ emissions simulated by the two models at global scale is very similar at around $15 \mathrm{Tg} \mathrm{yr}^{-1}$, but this is only around $25 \%$ of the icecore measured changes in $\left[\mathrm{CH}_{4}\right]$. The two models do show regional differences in emission sensitivity to climate with much larger magnitudes of northern and southern tropical anomalies in ORCHIDEE. However, the simulated northern and southern tropical anomalies partially compensate each other in both models limiting the net flux change. Future work may need to consider the inclusion of more detailed wetland processes (e.g. linked to permafrost or tropical floodplains), other non-wetland $\mathrm{CH}_{4}$ sources or different patterns of $\mathrm{D}-\mathrm{O}$ climate change in order to be able to reconcile emission estimates with the ice-core data for rapid $\mathrm{CH}_{4}$ events.

\section{Introduction}

Reconstructions from polar ice cores show that the atmospheric $\mathrm{CH}_{4}$ concentration $\left(\left[\mathrm{CH}_{4}\right]\right.$ ) has varied greatly as a function of past climate changes. Spectral analyses 
performed by Loulergue et al. (2008) indicate that the variability in $\left[\mathrm{CH}_{4}\right]$ over the last $800 \mathrm{kyr}$ is dominated by the $100 \mathrm{kyr}$ glacial-interglacial cycles and by the precessional component of Milankovitch cycles. Suggested underlying mechanisms involve a link between wetland extent and northern ice sheet dynamics as well as between the strengths of tropical sources/sinks and tropical climate patterns, for example through monsoon systems and via the position of the intertropical convergence zone (ITCZ) (Loulergue et al., 2008; Singarayer et al., 2011).

Large uncertainty remains surrounding to what extent the main natural source (wetlands) contributed to the glacialinterglacial change in $\left[\mathrm{CH}_{4}\right]$, and whilst earlier bottom-up modelling studies could not explain the glacial-interglacial change in $\left[\mathrm{CH}_{4}\right]$ with a reduction in wetland $\mathrm{CH}_{4}$ emissions alone in response to cooling and change in hydrological cycle (Kaplan et al., 2006; Valdes et al., 2005), more recent studies suggest that a modification in sink strength is neither required (Weber et al., 2010) nor reproduced by atmospheric chemistry model simulations (Levine et al., 2011).

Overlaid on the glacial-interglacial changes, the climate of the Pleistocene was also prone to a strong climatic variability on a millennial timescale, the most extreme feature of which is a series of abrupt jumps in Greenland temperature of between 8 and $16^{\circ} \mathrm{C}$ over the course of $10-40 \mathrm{yr}$ (e.g. Wolff et al., 2010). This abrupt warming called Dansgaard-Oeschger (D-O) events also have counterparts in the ice-core records of $\mathrm{CH}_{4}$, with $\mathrm{CH}_{4}$ jumps of up to two-thirds the glacialinterglacial concentration change. This suggests a coupling between climate changes associated with $\mathrm{D}-\mathrm{O}$ warming events and the global response of the $\mathrm{CH}_{4}$ biogeochemical cycles.

Until relatively recently, bottom-up modelling approaches over D-O events were limited not only by the lack of processbased representation of wetland $\mathrm{CH}_{4}$ emissions in land surface models, but also by the absence of climate forcing data representative of these events, necessary to drive wetland emission models. Recently, progress has been made in both directions. Firstly, a number of coupled ocean-atmosphere general circulation models (OAGCMs) have been used to simulate important paleoclimate events (e.g. Paleoclimate Model Intercomparison Project - PMIP1 then PMIP2; Braconnot et al., 2007) and in particular concerning climate transition and millennial-scale variation (e.g. Singarayer and Valdes, 2010; Kageyama et al., 2009). While many uncertainties remain, the most commonly invoked mechanism to explain the glacial millennial climate variability is related to different states of the Atlantic meridional overturning circulation (AMOC). OAGCMs can reproduce part of the D-O events (e.g. Kageyama et al., 2009) by starting at Last Glacial Maximum (LGM) equilibrium and then modifying AMOC by imposing freshwater perturbations in the North Atlantic (the so-called "water-hosing experiments").

Further, global models have been recently developed to incorporate explicitly wetland $\mathrm{CH}_{4}$ emissions in dynamic global vegetation models (DGVMs) (e.g. Wania et al., 2010; Riley et al., 2011; Ringeval et al., 2011, Petrescu et al., 2010). The strategy used to simulate wetland $\mathrm{CH}_{4}$ emissions varies from one DGVM to another. The differences between the models arise from both the choices made regarding the inclusion of certain processes (e.g. wetland extent dynamics) and in the representation of the sensitivity of a given process to the external drivers (e.g. the methanogenesis sensitivity to the temperature). Currently, an intercomparison between many global wetland $\mathrm{CH}_{4}$ emission models focusing on the current time period is in progress (WETCHIMP, Melton et al., 2012a).

To our knowledge, only one bottom-up modelling study (Hopcroft et al., 2011) investigated changes in global wetland $\mathrm{CH}_{4}$ emissions during transient $\mathrm{D}-\mathrm{O}$ events. The results of this study suggest that atmospheric changes driven by modifications of the AMOC induced $\mathrm{CH}_{4}$ variations from natural wetlands that are too small to explain the variation in $\left[\mathrm{CH}_{4}\right]$ observed in ice-cores during $\mathrm{D}-\mathrm{O}$ events. But the $\mathrm{CH}_{4}$ emission model in the global vegetation model (the Sheffield DGVM, called SDGVM hereafter) used in Hopcroft et al. (2011) is relatively simple, and the low sensitivity of SDGVM to climate change is one of the reasons advanced by the authors to explain the mismatch with the ice-core data. The scope of the present paper is to perform simulations using the same climate fields from an idealized D-O event as in Hopcroft et al. (2011) but with a processoriented and recently developed wetland emission model, the ORCHIDEE-WET model (Ringeval et al., 2010, 2011).

An intercomparison of the wetland $\mathrm{CH}_{4}$ emissions simulated during an idealized D-O event between the two models (SDGVM and ORCHIDEE-WET) is performed. Through this intercomparison, our purpose is to evaluate and understand a potential difference of modelled wetland $\mathrm{CH}_{4}$ emission sensitivity to climate change between the models.

Because (i) ORCHIDEE-WET has never been used to simulate the change in wetland $\mathrm{CH}_{4}$ emissions between the LGM and pre-industrial period (PI) and (ii) given the uncertainty remaining of the contribution of wetland emissions to LGM climate conditions, we will perform the intercomparison at first on the LGM-PI difference. Then we will focus on one idealized D-O event.

In Sect. 2, we describe the climate simulations and the two used wetland $\mathrm{CH}_{4}$ emission models. The intercomparison between the two models on both the LGM-PI transition and idealized D-O-event is performed in Sect. 3. Finally the results are discussed in Sect. 4.

\section{Methods}

\subsection{Climate simulations}

The climate simulated by the Fast Met Office UK Universities Simulator (FAMOUS: Smith et al., 2008) has been 
used to force two global vegetation models (GVMs), namely the Sheffield DGVM (SDGVM) and aversion of the ORCHIDEE model able to simulate the wetland $\mathrm{CH}_{4}$ emissions, ORCHIDEE-WET (see Sect. 2.2). FAMOUS is a low-resolution version $\left(5^{\circ} \times 7.5^{\circ}\right)$ of the UK Met Office's HadCM3 coupled general circulation model. FAMOUS has been used to simulate two equilibrium climates representative of the PI and the LGM. The boundary conditions relevant to the LGM are the $21 \mathrm{kyr}$ orbital configuration, the atmospheric concentrations of major greenhouse gases, the glaciation extent and the sea level, and these follow the PMIP protocol (Braconnot et al., 2007, http://pmip2.1sce.ipsl.fr/). The LGM climate of FAMOUS (Fig. A1) bears many similarities to that simulated by HadCM3 (Singarayer and Valdes, 2010), with a global mean cooling of $4.6^{\circ} \mathrm{C}$, that is similar to HadCM 3 and intermediate in the range of cooling magnitudes simulated with other coupled atmosphere-ocean GCMs analysed in PMIP2 (Braconnot et al., 2007). The simulated cooling is more intense over Greenland than in HadCM3, in better agreement with ice-core reconstructions. It also shows warming over the North Pacific and Alaska, the latter in reasonable agreement with terrestrial pollen-based mean annual temperature reconstructions (Bartlein et al., 2010). Over the tropics where proxy-based reconstructions are sparser, differences with HadCM3 are less pronounced, though regional differences in the patterns of the change in the ITCZ and hence precipitation are prominent, particularly in the eastern Pacific and South America. In addition to these two equilibrium simulations, starting from LGM conditions, freshwater forcing has been applied in the Atlantic Ocean in order to perturb the AMOC (Atlantic meridional overturning circulation) and to simulate the space/time patterns of climate during the simulated course of an idealized transient D-O event. During this idealized event, the Greenland temperature is characterized by a cold period (analogous to a Heinrich stadial, HS) then by a warm period (analogous to a Greenland interstadial, GI). The reader is referred to Sect. 2.3 of Hopcroft et al. (2011) for a full description of the FAMOUS simulations and resulting climate. The imposed freshwater forcing, the FAMOUS-simulated AMOC and Greenland temperature are given in Fig. A2. Hopcroft et al. (2011) also performed different simulations modifying the background climate from which the freshwater forcing is applied. Given the larger computational cost of the ORCHIDEE-WET model in comparison to SDGVM, we will use the outputs of only one FAMOUS climate simulation to force the DGVMs: the D-O simulation with LGM background, i.e. the reference $\mathrm{D}-\mathrm{O}$ simulation in Hopcroft et al. (2011).

\subsection{Wetland $\mathrm{CH}_{4}$ emission models}

SDGVM and ORCHIDEE-WET have been forced with FAMOUS climate output to simulate the wetland $\mathrm{CH}_{4}$ emissions during PI, LGM and over an idealized D-O event.
SDGVM and ORCHIDEE-WET are two models of different complexity and, regarding wetland $\mathrm{CH}_{4}$ emissions, have been used for different timescales: paleo-studies for SDGVM (Singarayer et al., 2011; Valdes et al., 2005) and studies over current (Bousquet et al., 2011; Ringeval et al., 2010) or future time period (Koven et al., 2011; Ringeval et al., 2011) for ORCHIDEE-WET.

ORCHIDEE-WET is more process-based than SDGVM in the computation of both the wetland extent dynamic and the $\mathrm{CH}_{4}$ flux densities. The wetland extent computation is based on a subgrid topographic approach in ORCHIDEEWET while it corresponds to a simple orographic correction in SDGVM. In ORCHIDEE-WET, the $\mathrm{CH}_{4}$ flux densities are computed from the process-based Walter et al. (2001) model, which accounts for a soil vertical discretization and for an explicit representation of $\mathrm{CH}_{4}$ transport from the soil to the atmosphere, whilst in SDGVM transport and vertical discretisation are ignored. The wetland extents computed in ORCHIDEE have been evaluated against remote sensing products of inundated area (Ringeval et al., 2012), and the $\mathrm{CH}_{4}$ flux densities have been optimized with site-level observations (Ringeval et al., 2010). The year-to-year variability of the wetland $\mathrm{CH}_{4}$ emissions reflects the wetland $\mathrm{CH}_{4}$ emission sensitivity to the climate variability. The ORCHIDEEWET simulated year-to-year variability in wetland emissions has been evaluated against top-down estimates over 19902000 (succinctly displayed in the Fig. 2 of Ringeval et al., 2011) and is being further analysed over the 1990-2009 period (I. Pison, personal communication, 2012), whilst the interannual variability of SDGVM has not been explored in detail. All of these elements increase our confidence in the modelled wetland emission sensitivity to the climate of ORCHIDEE-WET relative to SDGVM, at least over the current time period. The strategy followed here has been to perform the optimization under the current time period then to apply this model configuration in conditions representative of the LGM and the idealized D-O event.

The SDGVM model has already been described in Hopcroft et al. (2011). Thus, the following paragraphs mainly focus on ORCHIDEE-WET (Sect. 2.2.1) as well as on the differences of methodology used to compute the wetland $\mathrm{CH}_{4}$ emissions in the two models (Sect. 2.2.2). Similarly, only the ORCHIDEE-WET simulations will be presented (Sect. 2.2.3) and the reader should refer to Hopcroft et al. (2011) for more details of the SDGVM simulations.

\subsubsection{The ORCHIDEE-WET model}

In the ORCHIDEE-WET model, the wetland $\mathrm{CH}_{4}$ emissions $\left(E_{\mathrm{CH}_{4}}\right)$ are computed for each grid cell $g$ and for each time step $t$ through the following equation:

$$
\begin{aligned}
E_{\mathrm{CH}_{4}}(g, t)= & \sum_{\mathrm{WTD}_{i}} S_{\mathrm{WTD}_{i}}(g, t) \cdot D_{\mathrm{WTD}_{i}}(g, t) \\
& \text { with } \mathrm{WTD}_{i}=0 \text { and }-3 \mathrm{~cm}
\end{aligned}
$$


where $S_{\mathrm{WTD}_{i}}$ and $D_{\mathrm{WTD}_{i}}$ are respectively the extent (given as a grid cell fractional area) and the $\mathrm{CH}_{4}$ flux density of a wetland with a water table depth equal to $\mathrm{WTD}_{i}$. A negative value for $\mathrm{WTD}_{i}$ means that the WTD is below the soil surface. In the present study, not only the emissions of the inundated wetland (i.e. with WTD $=0$ ) are computed as in Ringeval et al. (2011), but also the emissions of wetlands with a mean water table equal to $-3 \mathrm{~cm}$ are also considered. This methodology is close to the one used in Bohn et al. (2007). $S_{\mathrm{WTD}_{i}}$ and $D_{\mathrm{WTD}_{i}}$ are computed by the coupling of ORCHIDEE-WET with respectively (i) a TOPMODEL approach and (ii) a slight modification of the Walter et al. (2001) model.

For each grid cell and at each time step, ORCHIDEE-WET simulates a soil water content resulting from a hydrologic budget accounting for some inputs (snowmelt and rainfall not intercepted by the canopy) and losses (soil evaporation, transpiration, sublimation, deep drainage, and surface runoff). This soil water content could be used to express a mean soil water deficit over the grid cell. This deficit is defined as a gap between the simulated soil water content and the maximum soil water content in the model, i.e. the soil field capacity. The coupling between ORCHIDEE-WET and TOPMODEL allows us to distribute the mean soil water deficit over each grid cell as function of the subgrid topographic index distribution. This leads to diagnosis of the fraction of the grid cell with a deficit equal to 0 . Then, the inundated wetland extents are computed from these "field capacity extents". In Ringeval et al. (2011), remote sensing data of inundated extent were used to do this computation. The mean climatology (average of 1993-2000) of the modelled field capacity extents were normalized to the same climatology of Prigent et al. (2007) data, and only the simulated temporal variability was kept. In order to prevent the use of current remote sensing data over paleo-timescale, a parameterization has been introduced. Briefly, the parameterization consists in a shift of the topographic index distribution in each grid cell. The shift value is the same for all grid cells and has been optimized to simulate a current global wetland fraction close to $4 \%$ (Prigent et al., 2007) at $1^{\circ}$ resolution when forced by the 1960-1991 CRU (http://www.cru.uea.ac.uk/) climatology. The reader is referred to Ringeval et al. (2012) for more details. The coarse-resolution effect on the wetland extent simulation through the coupling between ORCHIDEEWET and TOPMODEL is illustrated in Fig. A3. In particular, the loss of information in subgrid topographic index distribution due to the coarse resolution (Fig. A3d) leads to substantial difference in the wetland extents when compared to the a posteriori regrid of the $1^{\circ}$ simulated wetland extent (Fig. A3b). Nevertheless, the global wetland extent simulated at FAMOUS resolution is close to the value given by Prigent et al. (2007) dataset at the same resolution (Fig. A3c). As in Bohn et al. (2007), the coupling with TOPMODEL has been extended to compute wetland extents with a negative water table depth value. In Eq. (1), $S_{-3 \mathrm{~cm}}$ values are taken as extents given by TOPMODEL with a deficit between 0 and $-6 \mathrm{~cm}$.

The $\mathrm{CH}_{4}$ flux densities are computed using a slight modification of the Walter et al. (2001) model. As in Ringeval et al. (2010), the main modification of the original model concerns the use of the labile carbon pool simulated by ORCHIDEE-WET $\left(C_{\mathrm{L}}\right)$ to approach the methanogenesis substrate in such a way that the production rate for a soil layer $z$ and a time $t(\operatorname{Prod}(t, z))$ is defined as follows:

$\operatorname{Prod}(t, z)=\alpha_{0} \cdot f_{\mathrm{org}}(z) \cdot C_{\mathrm{L}}(t) \cdot H(T(t, z)) \cdot Q_{10}^{\left(T(z, t)-T_{\mathrm{ref}}\right) / 10}$

where $f_{\text {org }}$ is a function that vertically distributes the carbon in the soil, $H(T(t, z))$ is the Heaviside step function for the temperature, and $\mathrm{T}_{r e f}$ varies in space as in the Walter et al. (2001) model. In ORCHIDEE, the turnover time of the labile carbon pool is equal to 55 days. In the present study, $T_{\text {ref }}$ is defined as the mean surface temperature computed by ORCHIDEE-WET when forced by the 1960-1991 CRU (http://www.cru.uea.ac.uk/) climatology. The parameter $\alpha_{0}$, which contains both the fraction of the labile carbon pool that could be used as methanogenesis substrate and the base rate at $T_{\text {ref }}$, has been optimized against three sites (Abisko, Michigan or Panama) and then extrapolated at large band scale (Ringeval et al., 2010). As in Ringeval et al. (2011), identification of each grid cell to a wetland type (i.e. sharing the same optimized $\alpha_{0}$ as Abisko, Michigan or Panama) is based on a criterion of vegetation type. Through this interpolation, the assumption that the base rate at $T_{\text {ref }}$ co-varies with the amount of substrate is implicitly made. The optimization of $\alpha_{0}$ has been performed using CRU climatology at FAMOUS resolution at monthly time step. A $Q_{10}$ of 3 has been chosen at global scale for the methanogenesis sensitivity to temperature as in Ringeval et al. (2011). This value allows us to match the observed seasonal cycle of $\mathrm{CH}_{4}$ flux densities on both boreal and temperate sites.

\subsubsection{Differences between SDGVM and ORCHIDEE-WET}

Figure 1 summarizes the differences between the $\mathrm{CH}_{4}$ emission parameterizations of the two models. As succinctly mentioned above, the major differences between the two models are related to the computation of both the fractional area covered by a $\mathrm{CH}_{4}$ emitting wetland $(S)$ dynamic and the $\mathrm{CH}_{4}$ flux densities $(D)$. We describe the differences in the case of a given grid cell $g$ at time step $t$.

The methodology in SDGVM leads to a binary estimation of $S$, but allows the simulated WTD in a wetland to vary at monthly timescale from +10 to $-10 \mathrm{~cm}$. By contrast, the more process-oriented approach in ORCHIDEEWET, through its coupling with TOPMODEL, allows $S$ to vary continuously between 0 and 1 . Nevertheless, only two WTD classes ( 0 and $-3 \mathrm{~cm}$; cf. Eq. 1$)$ are considered in a given grid cell in ORCHIDEE-WET. 
$\mathrm{CH}_{4}$ emission models: differences between

\section{SDGVM}

- Used for paleo studies

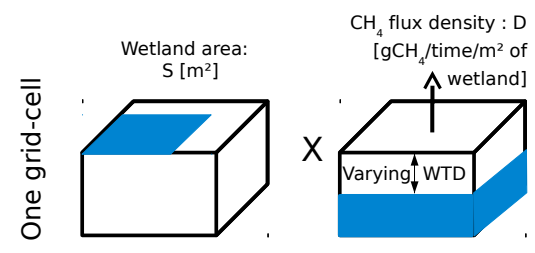

1) Wetland fraction (S)

- $S=0$ orf

- With $f_{\max }=1 \times$ orographic correction

2) $\mathrm{CH}_{4}$ flux density (D) computed following

(Cao et al., 1993)

- $D=$ prod - oxy

- With prod $=f(W T D) \cdot f(T) \cdot R_{H}$

- And oxy $=$ fixed $\%$ of prod

- Varying Water Table Depth (WTD)

- No transport

- Proxy for substrate $=$ the heterotophic respiation, $\mathrm{R}$

- In $f(T), Q_{10}=1.5$ and $T_{\text {ref }}$ is constant for all grid-cells

3) Vegetation dynamic: Yes

\section{ORCHIDEE}

- More process-based

- Used for studies on future/current time period

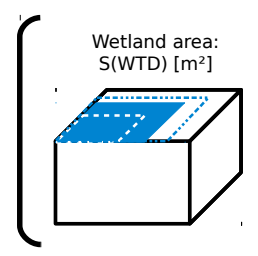

1) Wetland fraction (S)

- Use a subgrid-scale topographic approach (TOPMODEL)

- Compute a wetland fraction with a given WTD value

- Evaluated against remote sensing data of inundated area

2) $\mathbf{C H}_{4}$ flux density (D) computed following the process-based model of (Walter et al., 2001)

- Vertical discretization

- Production/oxidation/3 types of transport

- Proxy for substrate: mean labile carbon pool $\left(C_{L}\right)$

- For a given WTD value

- Evaluated against few data on sites

- in production, $Q_{10}=3.0$ and $T_{\text {ref }}$ varies from one grid-cell to

other. $T_{\text {ref }}$ is equal to the mean annual temperature given by the CRU climatology

3) Vegetation dynamic: No (but PI or LGM static vegetation)

Fig. 1. Summary of the methodology used to simulate the wetland $\mathrm{CH}_{4}$ emissions in SDGVM (left panel) and ORCHIDEE-WET (right panel).

In SDGVM, the wetland extent, $S$, is equal either to 0 or to $f_{\max }$ depending on a criterion varying with the latitude. This criterion is the value of the surface air temperature in boreal regions: the wetland presence in a given year starts for monthly temperature above $5{ }^{\circ} \mathrm{C}$ according to Fung et al. (1991). In the non-seasonally frozen environments, a positive difference between precipitation and evapotranspiration is required to reach $f_{\max } . f_{\max }$ is equal to the product of the entire area of $g$ and an orographic correction. In the wetland covered fraction $S \in\left\{>0, f_{\max }\right\}$ of a grid cell, a WTD value is computed following the Cao et al. (1996) relationship applied to the SDGVM soil water content. As in the Cao et al. (1996) model, the wetlands with the highest water table position allowed by the model $(+10 \mathrm{~cm})$ are considered as inundated and the others are called non-inundated wetlands $-\mathrm{a}$ distinction determining the $\mathrm{CH}_{4}$ flux density parameterization.

Regarding the $\mathrm{CH}_{4}$ flux density, the main differences between SDGVM and ORCHIDEE-WET relate to the soil physics vertical discretization, the accounting for $\mathrm{CH}_{4}$ transport from the soil to the atmosphere, the proxy of the methanogenesis substrate supply and the parameterization of the methanogenesis sensitivity to the temperature.
In SDGVM, the $\mathrm{CH}_{4}$ flux density for a given grid cell is estimated by the difference between a production and an oxidation rate. The methanogenesis rate is a function of the surface air temperature (T), the calculated WTD and the heterotrophic respiration through

$\operatorname{Prod}(t)=P_{0} \cdot R_{\mathrm{H}}(t) \cdot f(\mathrm{WTD}(t)) \cdot Q_{10}\left(T_{\mathrm{ref}}\right) \cdot Q_{10}^{\left(T(t)-T_{\mathrm{ref}}\right) / 10}$

where $P_{0}$ is a constant factor used to compute the base methanogenesis rate from the heterotrophic respiration $\left(R_{\mathrm{H}}\right)$. Thus, $R_{\mathrm{H}}$ could be considered as the proxy for the methanogenesis substrate as applied in the Cao et al. (1996) approach. $f$ (WTD) is equal to 1 in the case of the inundated wetland and decreases exponentially when the WTD decreases. The methanogenesis sensitivity to the temperature is parameterized using a $Q_{10}$ formulation with a $Q_{10}=1.5$ and a global constant reference temperature $T_{\text {ref }}=30^{\circ} \mathrm{C}$.

The oxidation rate is a given percent of the production (0.9) for non-inundated wetland and a function of gross primary production in the other wetlands. In ORCHIDEE-WET, following Ringeval et al. (2010), the flux density at the atmosphere/surface interface is the result of three processes: production in the soil layers below the WTD, oxidation above the WTD and transport by diffusion, ebullition and through plant aerenchyma. A soil vertical discretization is used as in 
the Walter et al. (2001) model. As for SDGVM, a $Q_{10}$ formulation defines the methanogenesis sensitivity to the temperature, but the $Q_{10}$ is here equal to 3 and the reference temperature ( $T_{\text {ref }}$ of the Eq. 2 ) varies in space. In ORCHIDEE-WET, oxidation only occurs in the soil layers above the WTD and is also a function of temperature.

The comparison of the results of the two models driven by glacial-interglacial and D-O climate changes will first focus on the change in emissions between different time periods. Then, to better understand the reason of eventual differences between the two models, we will compare the change in the different components of the wetland $\mathrm{CH}_{4}$ emissions (i.e. the wetland extents and the $\mathrm{CH}_{4}$ flux densities per unit of wetland) as in the Eq. (1). To compare more easily each component between the two models, we will compute them in the case of a saturated wetland. Thus, we will compare between the two models both the saturated wetland extent $\left(S_{0}\right)$ and the $\mathrm{CH}_{4}$ flux density for a saturated wetland $\left(D_{0}\right)$. These two variables are direct outputs of ORCHIDEE-WET $\left(\mathrm{WTD}_{i}=0\right.$ in Eq. 1). For SDGVM, the saturated wetland extents are defined a posteriori as the wetland extents with a water table depth above the soil surface (and below $+10 \mathrm{~cm}$, which is the prescribed maximum value). They encompass the so-called inundated wetlands by Cao et al. (1996) and the non-inundated wetlands with a WTD between $+10 \mathrm{~cm}$ and 0 . The 0 value is used as a threshold, because it is the maximum value allowed by the TOPMODEL approach (following Saulnier and Datin, 2004) used in ORCHIDEE-WET. For SDGVM, the $\mathrm{CH}_{4}$ flux densities for a saturated wetland are approached by dividing the simulated $\mathrm{CH}_{4}$ flux densities by $f$ (WTD), i.e. by the function used to decrease the potential methanogenesis rate depending on the WTD value.

\subsubsection{The ORCHIDEE-WET simulations}

The boundary conditions for the ORCHIDEE-WET simulations concern the soil texture (fractions of sand, silt and clay), the vegetation distribution and the orography/topography.

The soil texture maps come from the ISLSCP data (http: //badc.nerc.ac.uk/data/islscp/hydro.html) and are the same as the one used as input of SDGVM in Hopcroft et al. (2011). In ORCHIDEE-WET, a given grid cell represents the heterogeneous vegetation using a "mosaic" of 10 natural plant functional types (PFTs) and bare soil. The fraction of the grid cell occupied by each PFT is either calculated (and thus variable in time) or prescribed (Krinner et al., 2005). In the present study, dynamic vegetation is not activated; thus, vegetation maps are used as fixed boundary conditions. However, this does not prevent accounting for wetland extent dynamics (see above), which is decoupled from the vegetation dynamics in the ORCHIDEE-WET model. For the PI period, the vegetation map from the HYDE 3.0 database (Klein Goldewijk et al., 2007) is used. The prescribed LGM vegetation comes from Woillez et al. (2011). Contrary to SDGVM, the LGM vegetation is static during the entire transient $\mathrm{D}-\mathrm{O}$ simulations in ORCHIDEE-WET.

The mean altitude of each grid cell is taken from the orography boundary condition used in FAMOUS and is derived from the ICE-5G data (Peltier, 2004). The mean altitude is used to derive the surface atmospheric pressure. The altitude is considered constant during the $\mathrm{D}-\mathrm{O}$ run. Concerning the subgrid topography necessary as input of ORCHIDEE-WET through its coupling with TOPMODEL, we use the current subgrid topography given by HYDRO1k (http://webgis.wr.usgs.gov/globalgis/ metadata_qr/metadata/hydro1k.htm) for all the simulated time periods. Thus, it is implicitly assumed that the largescale (i.e. the mean altitude of each grid cell) and the smallscale topography are independent. As described in Decharme and Douville (2007) and Ringeval et al. (2012), the spatial distribution of the topographic indices in each grid cell is derived from the mean, standard deviation, and skewness of the actual distribution using a three parameter gamma distribution. For the grid cells for which the continental fraction increases from PI to LGM, the same statistical variables as for the PI are used to extend the subgrid distribution to the new land part of the grid cell. For entirely new grid cells under LGM conditions, we use the subgrid topography distribution of the closest grid cell existing under PI conditions. This strategy had to be applied only for few grid cells as compared to the previous case (increase of continental fraction in PI existing grid cells). An optimal alternative would have been to use the bathymetry data (e.g. http: //www.ngdc.noaa.gov/mgg/bathymetry/relief.html) for these new grid cells (J. O. Kaplan, personal communication, 2011). No changes in the topography/orography are accounted for during the transient $\mathrm{D}-\mathrm{O}$ run for the two models, and they are fixed to LGM conditions. Note also that the sea level is considered constant during the $\mathrm{D}-\mathrm{O}$ transient run as in Hopcroft et al. (2011).

A spin-up run of several thousand of years was performed to bring all ORCHIDEE-WET carbon pools to their longterm equilibrium values for both the PI and LGM conditions. A 30-yr interannual simulation was then carried out for both the PI and the LGM with year-to-year variability deriving from FAMOUS and is used to perform the intercomparison with SDGVM.

In the present study, three ORCHIDEE-WET configurations named hereafter V0, V1 and V2 have been used (see Table 1). V0 is the standard ORCHIDEE-WET set-up. The aim of the two other configurations is either to estimate the contribution of different parameterizations to potential differences between ORCHIDEE-V0 and SDGVM, or to better understand the wetland $\mathrm{CH}_{4}$ emission sensitivity to climate in ORCHIDEE-WET.

V1 differs from V0 by a change in the parameterization of the methanogenesis sensitivity to temperature. The same sensitivity as in SDGVM is used in V1. It corresponds to a spatially invariant $T_{\text {ref }}$ equal to $30^{\circ} \mathrm{C}$ and $Q_{10}=1.5$. As 
Table 1. Description of the different ORCHIDEE-WET simulations (ORCHIDEE-V0, V1, V2 and opt).

\begin{tabular}{|c|c|c|c|c|}
\hline & ORCHIDEE-WET - V0 & ORCHIDEE-WET - V1 & ORCHIDEE-WET - V2 & ORCHIDEE-WET - opt \\
\hline $\begin{array}{l}\text { General } \\
\text { description }\end{array}$ & $\begin{array}{l}\text { Standard ORCHIDEE- } \\
\text { WET set-up }\end{array}$ & $\begin{array}{l}\text { As ORCHIDEE-WET - V0 } \\
\text { with the same } \\
\text { methanogenesis } \\
\text { sensitivity to the } \\
\text { temperature as SDGVM }\end{array}$ & $\begin{array}{l}\text { As ORCHIDEE-WET - V1 } \\
\text { with prescribed soil } \\
\text { water content to } \\
\text { compute the } \mathrm{CH}_{4} \text { flux } \\
\text { densities }\end{array}$ & "Optimal" version \\
\hline$Q_{10} / T_{\text {ref }}$ & $\begin{array}{l}Q_{10}=3 \\
\text { Space-varying } T_{\text {ref }} \text {. } \\
\text { For each grid cell, } \\
T_{\text {ref is equal to the }} \\
\text { mean yearly surface } \\
\text { temperature } \\
\text { computed by } \\
\text { ORCHIDEE-WET } \\
\text { when forced by the } \\
1960-1991 \text { CRU } \\
\text { climatology }\end{array}$ & $\begin{array}{l}Q_{10}=1.5 \\
T_{\text {ref }}=30^{\circ} \mathrm{C} \\
\text { everywhere }\end{array}$ & $\begin{array}{l}Q_{10}=1.5 \\
T_{\text {ref }}=30^{\circ} \mathrm{C} \\
\text { everywhere }\end{array}$ & $\begin{array}{l}Q_{10}=3.0 \\
T_{\text {ref }}=30^{\circ} \mathrm{C} \\
\text { everywhere }\end{array}$ \\
\hline $\begin{array}{l}\text { Way to } \\
\text { compute } \alpha_{0} \\
\text { and value for } \\
\text { the different } \\
\text { latitude bands } \\
\text { (temperate, } \\
\text { boreal, } \\
\text { tropical) (in } \\
10^{-6} \mathrm{~m}^{-2} \text { month }^{-1} \text { ) }\end{array}$ & $\begin{array}{l}\text { Optimized against } \\
\text { three sites then } \\
\text { extrapolated at } \\
\text { latitude band scale } \\
\text { as in Ringeval et al. } \\
(2010) \\
(1.1,2.2,17.5)\end{array}$ & $\begin{array}{l}\text { Optimized against } \\
\text { three sites then } \\
\text { extrapolated at } \\
\text { latitude band scale } \\
\text { as in Ringeval et al. } \\
(2010) \\
(5.5,8.5,20.1)\end{array}$ & $\begin{array}{l}\text { For each sites, equal } \\
\text { to } \alpha_{0}(\text { ORCHIDEE-V1) } \\
C_{\text {sol }}(\text { ORCHIDEE-V2)/ } \\
C_{\text {sol }}(\text { ORCHIDEE-V1) } \\
\text { then extrapolated at } \\
\text { latitude band scale } \\
(6.9,5.4,24.5)\end{array}$ & $\begin{array}{l}\text { For each sites, equal } \\
\text { to } \alpha_{0}(\text { ORCHIDEE-V1) } \\
C_{\text {sol }}(\text { ORCHIDEE-Vopt }) / \\
C_{\text {sol }}(\text { ORCHIDEE-V1) } \\
\text { then extrapolated at } \\
\text { latitude band scale } \\
(34.8,21.1,37.6)\end{array}$ \\
\hline $\begin{array}{l}\text { Soil water } \\
\text { conditions } \\
\text { used to } \\
\text { compute the } \\
\mathrm{CH}_{4} \text { flux } \\
\text { densities }\end{array}$ & $\begin{array}{l}\text { Computed by the } \\
\text { model }\end{array}$ & $\begin{array}{l}\text { Computed by the } \\
\text { model }\end{array}$ & $\begin{array}{l}\text { Prescribed: constant } \\
\text { in time and space } \\
\text { and equal to the } \\
\text { maximum soil water } \\
\text { content in the model }\end{array}$ & $\begin{array}{l}\text { Prescribed: constant } \\
\text { in time and space } \\
\text { and equal to the } \\
\text { maximum soil water } \\
\text { content in the model }\end{array}$ \\
\hline
\end{tabular}

explained in Sect. 2.2.1, the parameter $\alpha_{0}$, which represents the fraction of the labile carbon pool that could be used as methanogenesis substrate, accounts also for a methanogenesis base rate at $T_{\text {ref. }}$ A change in $T_{\text {ref }}$ and $Q_{10}$ requires a new optimization of $\alpha_{0}$ that we performed on the same three sites as for ORCHIDEE-V0 (see Table 1). The fact that $T_{\text {ref }}$ is constant could lead to differences in the spatial distribution of emissions in each latitude band sharing the same $\alpha_{0}$ value as compared to V0. Through the V1 simulation, we aim to estimate the role played by the $Q_{10}$ formulation on the difference between SDGVM and ORCHIDEE-V0. V1 is closer to SDGVM than V0. Note, however that using such a low $Q_{10}$ value in ORCHIDEE-WET leads to poor agreement between the simulated and observed seasonal cycles of $\mathrm{CH}_{4}$ flux densities for present-day site-level observations (not shown).

Finally, ORCHIDEE-V2 differs from V1 through the prescription of the maximum soil water content in each grid cell and at each time step to compute the carbon cycle. That means we fixed the soil moisture at its field capacity everywhere regardless of the soil water budget, in the computation of the different carbon pools. The computation of the wetland extent is not affected by this operation: the ORCHIDEE-V1 modelled wetland fractions are combined with such $\mathrm{CH}_{4}$ flux densities to compute the $\mathrm{CH}_{4}$ emissions. Moreover, the values of the water table used to compute the $\mathrm{CH}_{4}$ flux densities are the same in V0 and V1 (cf. Eq. 1). However, prescribing maximum soil water content during the carbon cycle computation allows removing what we consider as a bias of the methodology used in ORCHIDEE-WET (see also Sect. 4). In fact, in ORCHIDEE-WET, a subgrid approach (TOPMODEL) is used to diagnose the wetland fraction of each grid cell. But this subgrid treatment has no effect on the carbon cycle computation and in particular on the moisture dependence of decomposition. Indeed, there is no wetland PFT and thus no subgrid wetland/non-wetland distinction to compute the carbon cycle variables. Instead of this, the mean value of the labile soil carbon content over the grid cell $\left(C_{\mathrm{L}}\right.$ in the Eq. 2$)$ is used as the wetland substrate. Thus the methanogenesis substrate is sensitive to change in precipitation in the model while it would be less sensitive in 

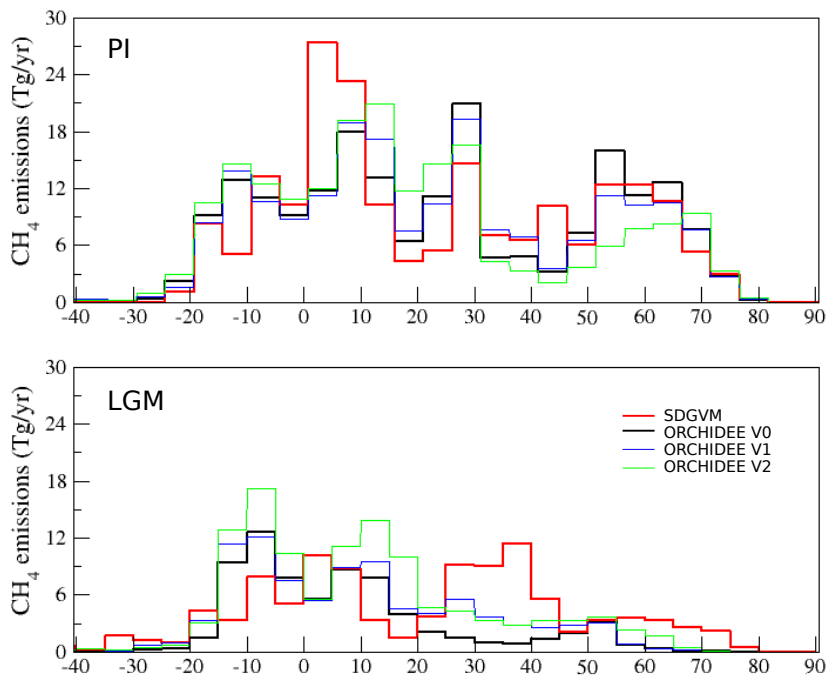

Fig. 2. Latitudinal distribution of the PI (top panel) and LGM (bottom panel) $\mathrm{CH}_{4}$ emissions for SDGVM (red) and the different ORCHIDEE-WET simulations. Each PI ORCHIDEE-WET latitudinal distribution has been scaled to match the SDGVM PI global emissions. The same scaling factor has been applied for each LGM ORCHIDEE-WET distribution.

the reality for a continually saturated wetland. The strategy used in V2 allows us to treat each grid cell as a saturated wetland and to remove the effects of the temporal variability in the soil water content on the carbon cycle variables necessary to compute the $\mathrm{CH}_{4}$ flux densities. This leads to a modification of the latitudinal distribution of the wetland $\mathrm{CH}_{4}$ emissions as compared to V1 and in particular to lower boreal emissions (cf. Fig. 2). $\alpha_{0}$ is not again optimized on sites, but a correction is applied to the V1 value (cf. Table 1). Note finally that using constant soil field capacity conditions has an effect not only on the substrate but also on the surface temperature and on the net primary productivity (NPP), which could both additionally modify $\mathrm{CH}_{4}$ emissions, through the methanogenesis and transport respectively. However, these effects are estimated to be of second order in comparison to the effect on the substrate (not shown).

In order to better compare our simulation results with wetland $\mathrm{CH}_{4}$ emission estimates from ice-core data, a final ORCHIDEE simulation, hereafter called ORCHIDEE-opt, has been performed. In this simulation, as in ORCHIDEE-V2, the substrate sensitivity to precipitation is removed. However, a space-constant $T_{\text {ref }}$ is used as well as a $Q_{10}$ equal to 3 . The aim of the previous configurations (V1 and V2) was either to estimate the contribution of different parameterizations to potential differences between ORCHIDEE-V0 and SDGVM, or to better understand the wetland $\mathrm{CH}_{4}$ emission sensitivity to climate in ORCHIDEE-WET. The aim of ORCHIDEE-opt is to provide our best ORCHIDEE estimates of the change in wetland emissions. These estimates will be exclusively discussed in Sect. 4 .

\section{Results}

\subsection{LGM-PI}

\subsubsection{Magnitude and latitudinal distribution of the LGM-PI change in emissions}

The basic parameterization of the two models leads to larger simulated PI emissions in ORCHIDEE-WET than in SDGVM (275 vs. $197 \mathrm{Tg} \mathrm{yr}^{-1}$; Table 2) but with a similar latitudinal distribution at FAMOUS resolution (Fig. 2, Fig. 3, left side). The ORCHIDEE-WET PI emissions are slightly higher than previous estimates (e.g. Chappellaz et al., 1993). This apparent over-estimation against commonly accepted values was also obtained over the period 19902000 (Ringeval et al., 2011). Contrary to some other studies (e.g. Spahni et al., 2011), the global ORCHIDEE-WET emissions had not been calibrated to match other estimates. Instead of this, the model has been independently tuned to reproduce the wetland extent against remote sensing data and the $\mathrm{CH}_{4}$ flux densities against sites measurements. This underlines the uncertainty linked to the contribution of the wetlands to the global $\mathrm{CH}_{4}$ budget (Melton et al., 2012a and S. Kirschke, personal communication, 2012).

Both (i) the global magnitude and (ii) the latitudinal distribution of the LGM-PI change are different between SDGVM and ORCHIDEE-V0. The global decrease of emissions in LGM as compared to PI is higher in ORCHIDEE-V0 than in SDGVM (respectively. -67 vs. $-46 \%$ ) (cf. Table 2 for values in both $\mathrm{Tg} \mathrm{yr}^{-1}$ and percent). Both models lead to higher decrease during LGM than the range given by Weber et al. (2010) (35-42\%), which focused on the effect of the uncertainty in the LGM climate modelling on the wetland $\mathrm{CH}_{4}$ emissions using a very simple wetland $\mathrm{CH}_{4}$ emission parameterization (see Sect. 4). Here the lower LGM wetland $\mathrm{CH}_{4}$ emissions simulated by ORCHIDEE-WET could completely explain the observed change in $\left[\mathrm{CH}_{4}\right]$ as suggested by previous top-down studies, e.g. Chappellaz et al. (1997) and Dallenbach et al. (2000), while these approaches have their own limitation (see e.g. Baumgartner et al., 2012).

In ORCHIDEE-V0, the LGM decrease of $\mathrm{CH}_{4}$ emissions in northern latitudes $\left(>30^{\circ} \mathrm{N}\right)$ is higher than the decrease in tropics $\left(30^{\circ} \mathrm{S}-30^{\circ} \mathrm{N}\right)$ while they are of the same magnitude in both latitude bands in SDGVM (Table 2; Fig. 2, bottom panel). Boreal wetland emissions are almost shut down in ORCHIDEE-WET (decrease of 88-97\% in emissions northwards of $60^{\circ} \mathrm{N}$ ), which seems to be in agreement with the large drop of boreal wetland emissions in LGM inferred by Fischer et al. (2008) using $\mathrm{CH}_{4}$ isotopic information from ice cores. 
Table 2. PI, LGM and LGM-PI wetland $\mathrm{CH}_{4}$ emissions for SDGVM and ORCHIDEE. In the top row, the global PI and LGM emissions are given in $\mathrm{Tg}_{r}-1$. For ORCHIDEE-WET, the first number in brackets corresponds to the emissions from saturated wetland while the second number refers to the emissions from non-saturated wetlands. In the bottom row, the LGM-PI change (in percent) is given for different latitudinal bands. In the bottom row, numbers in square brackets correspond to tests performed to evaluate the sensitivity to change in latitudinal distribution due to modification of $\alpha_{0}$ (please refer to the text in Sect. 3.1.1).

\begin{tabular}{lcrrcc}
\hline Tg yr $^{-1}$ & SDGVM & ORCHIDEE-WET V0 & ORCHIDEE-WET V1 & ORCHIDEE-WET V2 & ORCHIDEE-WET opt \\
\hline Global PI & 197 & $275(203+72)$ & $259(191+68)$ & $236(174+62)$ & $229(168+61)$ \\
Global LGM & 106 & $90(65+25)$ & $128(92+36)$ & $161(117+44)$ & $146(106+40)$ \\
\hline LGM-PI $(\%)$ & SDGVM & ORCHIDEE-WET V0 & ORCHIDEE-WET V1 & ORCHIDEE-WET V2 & ORCHIDEE-WET opt \\
\hline Global & $-46 \%$ & $-67 \%$ & $-51 \%[-50 \%]$ & $-32 \%[-35 \%]$ & $-36 \%[-38 \%]$ \\
$>30^{\circ} \mathrm{N}$ & $-41 \%$ & $-87 \%$ & $-75 \%[-73 \%]$ & $-52 \%[-64 \%]$ & $-45 \%[-58 \%]$ \\
$30^{\circ} \mathrm{S}-30^{\circ} \mathrm{N}$ & $-48 \%$ & $-57 \%$ & $-39 \%[-39 \%]$ & $-25 \%[-23 \%]$ & $-32 \%[-30 \%]$ \\
\hline
\end{tabular}

PI wetlands $\mathrm{CH}_{4}$ emissions
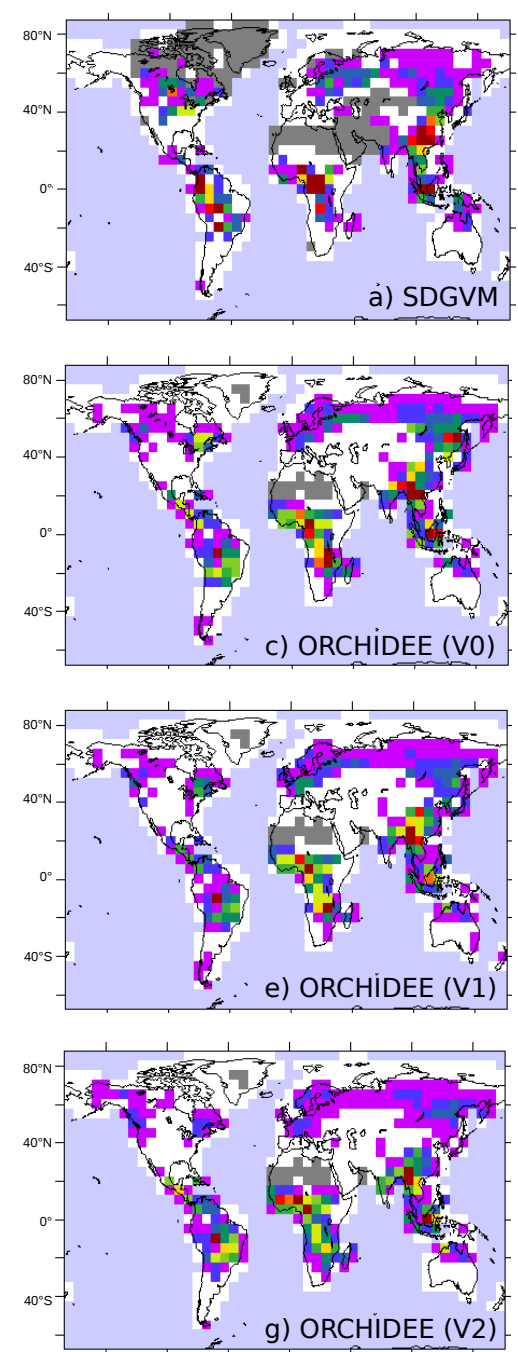

LGM - PI change in wetlands $\mathrm{CH}_{4}$ emissions
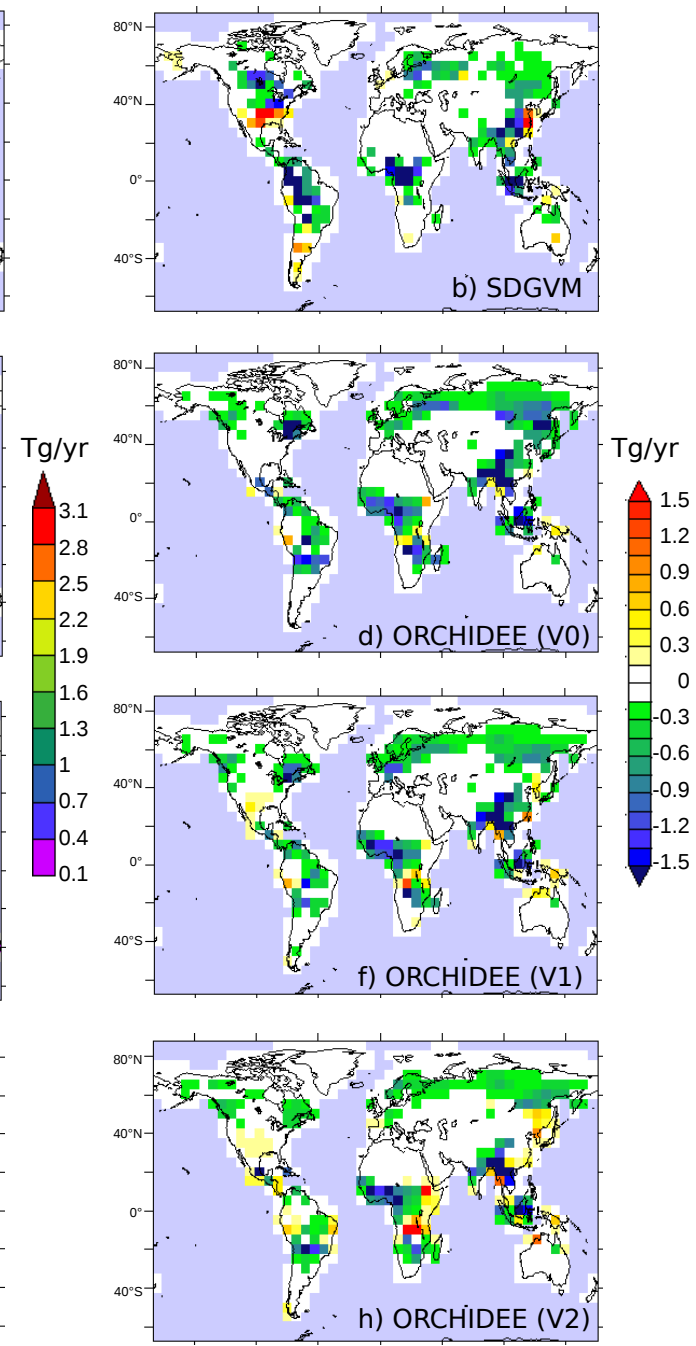

Fig. 3. Left panels: PI emissions $\left(\mathrm{Tg}^{-1}\right)$ for SDGVM (a) and for the different ORCHIDEEWET versions (c, e, g). Right panels: LGM-PI change $\left(\mathrm{Tg} \mathrm{yr}^{-1}\right)$ for each model (b: SDGVM and $\mathbf{d}, \mathbf{f}, \mathbf{h}$ : different ORCHIDEE-WET versions). The same scaling as for Fig. 2 is applied to the ORCHIDEE-WET plots. Grey areas correspond to grid cells without any vegetation. 

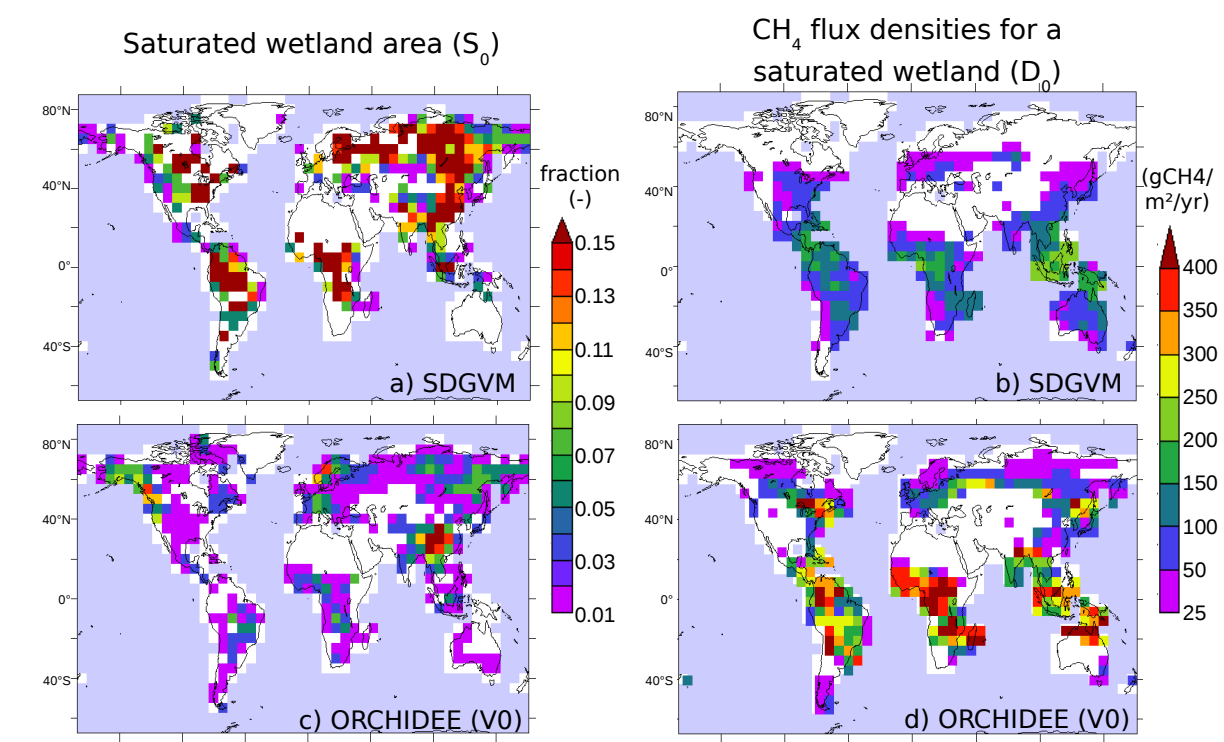

Fig. 4. Components of the PI emissions for each model (SDGVM and ORCHIDEE-V0). Left panels: saturated wetland extent (in grid cell fraction); right panels: $\mathrm{CH}_{4}$ flux densities for a saturated wetland $\left(\mathrm{g} \mathrm{CH}_{4} \mathrm{~m}^{-2} \mathrm{yr}^{-1}\right)$. As for Fig. 3, grey areas correspond to grid cells without any vegetation.

The different LGM-PI change at global scale between the two models could be reconciled by prescribing the same $Q_{10}$ formulation to quantify the methanogenesis sensitivity to temperature in each model (Table 2, SDGVM and ORCHIDEE-V1). This underlines the large consequence of the uncertainty relating to particular key parameters. Contrary to the global magnitude of the LGM-PI difference, the latitudinal distribution of this difference cannot be easily reconciled between the two models: the decrease in the $>30^{\circ} \mathrm{N}$ region is higher than the one in $30^{\circ} \mathrm{S}-30^{\circ} \mathrm{N}$ whatever the ORCHIDEE-WET version and in contrast with SDGVM (Table 2). The amount of $\alpha_{0}$ change from one ORCHIDEE version to the other one is not the same for the three big latitude bands sharing the same $\alpha_{0}$ parameter. This could contribute to modify the contribution of each latitude band to the global signal. A posteriori sensitivity tests have been performed by applying correcting scaling factors to obtain, in each version, exactly the same contribution of each big latitude band to the global PI emissions as in V0. The LGM-PI difference has been computed using such "correcting" emissions and is indicated in Table 2. This correction then ensures that the primary influence of the change between the versions is not related to change in $\alpha_{0}$.

\subsubsection{Factors explaining the difference in the LGM-PI change in emissions between the two models}

To explain the differences between the two models, we examine the two components of the emissions as explained in Sect. 2.2.3: the saturated wetland extent $\left(S_{0}\right)$ vs. the $\mathrm{CH}_{4}$ flux density for a saturated wetland $\left(D_{0}\right)$. We focus also on the drivers of the sensitivity of each component to the climate. At first, Fig. 4 shows the components of the PI emissions for both models (top panels for SDGVM and bottom ones for ORCHIDEE). The contribution of each component to the PI emissions is very different between SDGVM and ORCHIDEE-WET (Fig. 4). Indeed, the mean yearly PI $D_{0}$ over the globe for SDGVM is about half the ORCHIDEE-V0 value (respectively 47.4 and $87.5 \mathrm{~g} \mathrm{CH}_{4} \mathrm{~m}^{-2} \mathrm{yr}^{-1}$ ). Given the relatively similar global PI emissions between the two models (Fig. 2), the opposite relationship is obtained for the mean saturated wetland component $\left(S_{0}\right)$. In the Figs. 5 and 6 , the LGM-PI change of each component will be expressed in percent of its PI value because of the difference of PI value between the two models.

The role played by the changes in wetland extent in explaining the LGM-PI difference in emissions is weak in the two models (Figs. 3 and 5). Thus, the impact of the additional complexity of the hydrological scheme employed in ORCHIDEE-WET compared to in SDGVM has only a limited effect on the LGM-PI difference in $\mathrm{CH}_{4}$ emissions. The change in wetland extent between LGM and PI is partially due to the change in both continental ice sheets (decrease of land area available for wetlands) and continental shelves (increase in land area available for wetlands), which are named "geographic effects" in Weber et al. (2010). The contribution of the "geographic effects" to the change in emission is close in the two models. Indeed, the gain of emissions during PI over areas covered by continental ice-sheets during LGM is 16 and $19 \mathrm{Tg} \mathrm{yr}^{-1}$ for SDGVM and ORCHIDEE, respectively. In the same way, the loss of emissions during PI due to shrinking continental shelves area (higher sea level) is of 13 and $11 \mathrm{Tg} \mathrm{yr}^{-1}$ for SDGVM and ORCHIDEE, 


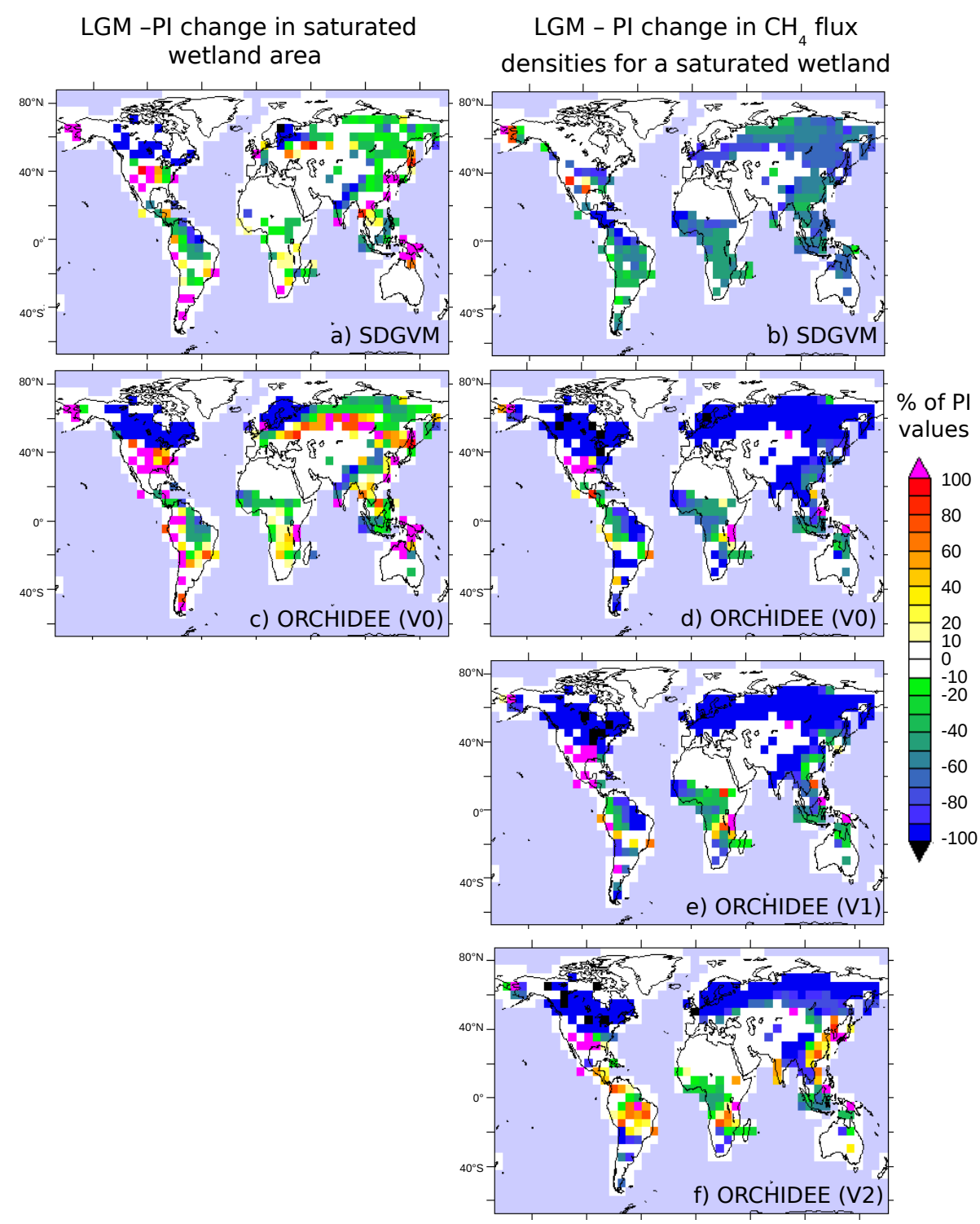

Fig. 5. LGM-PI change of each component of the $\mathrm{CH}_{4}$ emissions (in percent of its PI value) for SDGVM (a-b) and the different ORCHIDEEWET versions (c-f). Left panels: saturated wetland area; right panels: $\mathrm{CH}_{4}$ flux densities for a saturated wetland.

respectively. These effects nearly oppose each other, and together do not contribute to the global difference between the two models. However, the simple treatment used to estimate the subgrid topography of the new land surface during the LGM (i.e. the extrapolation from nearby land grid cells) does not allow a comprehensive analysis of the role of coastal shelf regions in LGM-PI wetland $\mathrm{CH}_{4}$ emissions.

The lower LGM emissions in boreal regions in ORCHIDEE-WET as compared to PI values are mainly explained by a drop in the $\mathrm{CH}_{4}$ flux densities (Fig. 5). In ORCHIDEE, the main driver of the LGM-PI $\mathrm{CH}_{4}$ flux densities change is the decrease from PI to LGM in substrate supply (Fig. 6). Indeed, the effect of the change in temperature on the methanogenesis rate is low (compare ORCHIDEE-V0 and ORCHIDEE-V1 in Fig. 5). The large decrease in the substrate availability computed by ORCHIDEE in LGM as compared to PI is not simulated by SDGVM and explains the difference of behaviour between the two models. Between the two equilibrium states (LGM and PI), the change in substrate supply is caused by a change of input, reflecting change in the NPP. In ORCHIDEE, the large decrease in NPP in LGM seems to be mainly driven by a change in NPP flux density per vegetation type rather than by a change in vegetation coverage (Fig. A4a-b). In particular, the increase in summer vegetation moisture stress in ORCHIDEE-WET from PI to LGM is a major contributor to the decrease in NPP (see Fig. A4). Soil freezing processes that limit the availability of liquid water to plants are accounted for in ORCHIDEE 
LGM - PI change in the proxy of methanogenesis substrate

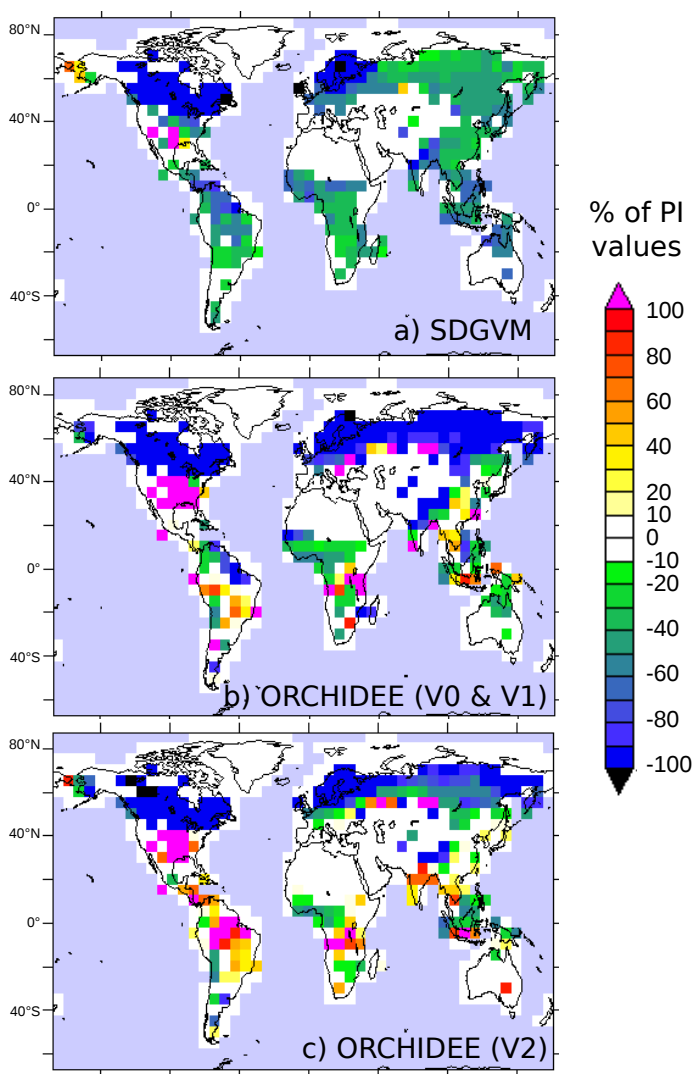

Fig. 6. LGM-PI change in the proxy of methanogenesis substrate in each model (in percent of its LGM values). (a) Heterotrophic respiration for SDGVM. $(\mathbf{b}, \mathbf{c})$ Soil labile carbon pool for ORCHIDEE.

and not in SDGVM, which could explain the lower NPP and substrate availability in ORCHIDEE compared to SDGVM. Note that the contribution of climate vs. $\mathrm{CO}_{2}$ in the LGMPI change in NPP has not been compared between the two models. The contribution of each process in ORCHIDEE is discussed in Woillez et al. (2011, Fig. 15) while the model version used in this latter study does not include representation of soil water freeze/thaw.

It seems that the difference of chosen proxy for the substrate between the two models (heterotrophic respiration (HR) in SDGVM vs. labile carbon pool in ORCHIDEE) plays a minor role: in ORCHIDEE, the LGM-PI change in $\mathrm{HR}$ is similar to the change in active carbon pool (not shown).

\subsection{D-O events}

\subsubsection{Change in emissions at global scale and contribution of the tropics vs. extra-tropics}

We now analyse the changes in the wetland $\mathrm{CH}_{4}$ emissions over one idealized $\mathrm{D}-\mathrm{O}$ event and in particular during two key-periods relative to the LGM: (i) the cold period corresponding to the AMOC off phase and here denoted as analogous to a Heinrich stadial (HS) and (ii) the warm period corresponding to the strong overturning behaviour and denoted as analogous to a Greenland interstadial (GI). The LGM, the HS and the GI periods are respectively delimited by the following transient simulation years: $1-30,151-180$ and 301-330.

The amplitude of the change in wetland $\mathrm{CH}_{4}$ emissions between the warm and cold periods of the $\mathrm{D}-\mathrm{O}$ is very similar between the two models (SDGVM and ORCHIDEEV0, Fig. 7, top panel). During the cold period of the D-O (HS), the wetland $\mathrm{CH}_{4}$ emissions are $5.7 \%$ lower in comparison to LGM values for SDGVM, while this decrease is of $3.3 \%$ for ORCHIDEE. The change during the warm period of the $\mathrm{D}-\mathrm{O}(\mathrm{GI})$ relative to the LGM value is slightly larger in ORCHIDEE-V0 than in SDGVM (respectively +11.5 and $+8.5 \%$ ) leading to very similar GI-HS differences for the two models $(+14.2$ for SDGVM and $+14.8 \%$ for ORCHIDEE). Despite this consistent global picture in the two models, the contribution of each latitude band to the global $\mathrm{D}-\mathrm{O}$ change (Fig. 7, bottom panel) is very different between ORCHIDEE and SDGVM. The northern regions $\left(>30^{\circ} \mathrm{N}\right)$ play a minor role in the global signal in ORCHIDEE-V0 contrary to the situation in SDGVM. For instance, this latitude band explains $53 \%$ of the global GI-LGM difference in emissions in SDGVM and only $28 \%$ in ORCHIDEE-V0. The difference between the two models regarding the latitudinal distribution of the $\mathrm{D}-\mathrm{O}$ change in emissions can be totally explained by the much lower LGM emissions of the $>30^{\circ} \mathrm{N}$ band in ORCHIDEE-V0 than in SDGVM. Indeed, the variation of the extra-tropical latitude band normalized by the LGM boreal emissions is higher in ORCHIDEE-V0 than in SDGVM (not shown). In the later case, the higher boreal emission sensitivity to $\mathrm{D}-\mathrm{O}$ climate changes obtained with ORCHIDEE-V0 is explained by its higher $Q_{10}$ value (3 against 1.5 in SDGVM).

Concerning the tropics, ORCHIDEE-V0 shows a HSLGM change of the same amplitude as SDGVM but a larger increase in the emissions during GI relative to LGM $(+4.2$ for SDGVM and $+8.2 \%$ for ORCHIDEE-V0). Moreover, it seems the tropical HS-LGM change in ORCHIDEE-WET is very sensitive to the different parameterizations (Fig. 7; differences between V0, V1 and V2) with, surprisingly, a positive HS-LGM difference simulated by ORCHIDEE-V1. Thus, while we obtain the same picture at global scale for the two models, the underlying drivers of the sensitivity of each model are not the same, in particular in the tropics. To investigate this, we now examine the contribution of each component $\left(\mathrm{CH}_{4}\right.$ flux densities vs. wetland extent) to the modelled emission change between LGM, HS and GI.

\subsubsection{Drivers of the change in emissions}

We have carried out sensitivity analysis to assess the contribution of wetland extent vs. $\mathrm{CH}_{4}$ flux density to the 

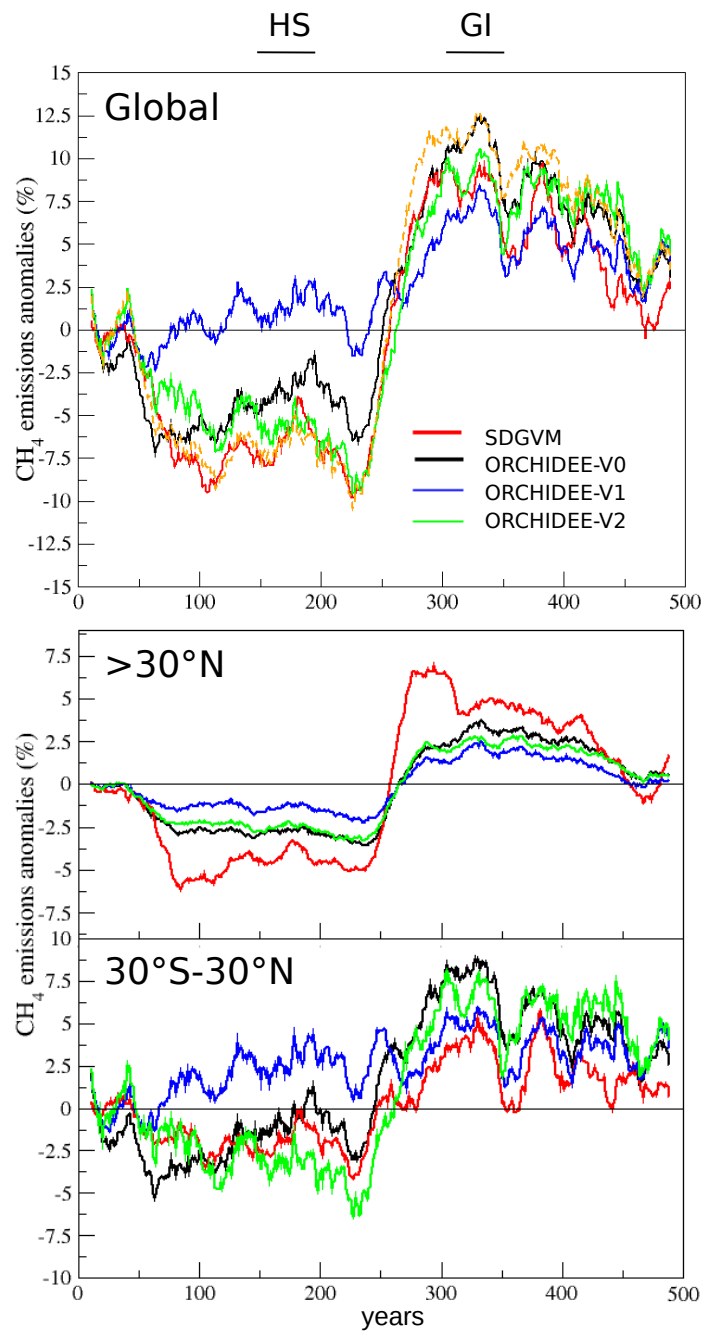

Fig. 7. Evolution of the $\mathrm{CH}_{4}$ emissions during D-O events at global (top panel), extra-tropical $\left(>30^{\circ} \mathrm{N}\right.$, middle) and tropical (bottom panel) latitude bands (in percent of the global LGM emissions) and computed using moving mean over $20 \mathrm{yr}$. The evolution of global emissions over the D-O event simulated by the ORCHIDEE-opt version is added as a dashed orange curve.

difference in $\mathrm{CH}_{4}$ emissions between LGM, HS and GI. In each latitude band, we computed the annual $\mathrm{CH}_{4}$ emission anomalies relative to the mean global LGM value for the HS and GI periods using the simulations described above. These anomalies are called VAR in the following. We have also computed the annual $\mathrm{CH}_{4}$ emission anomalies in the case where the wetland extent is prescribed and equal for each grid cell to its mean LGM value in the respective ORCHIDEE and SDGVM simulation. These $\mathrm{CH}_{4}$ emission anomalies are denoted as FIXED. Figure 8 displays scatter plots of FIXED against VAR. In Fig. 8, the two triangles delimited by the $\mathrm{x}$-axis and the $1: 1$ line encompass model behaviour in which both the flux density and the wetland extent anomalies have the same sign. In these triangles, the closer
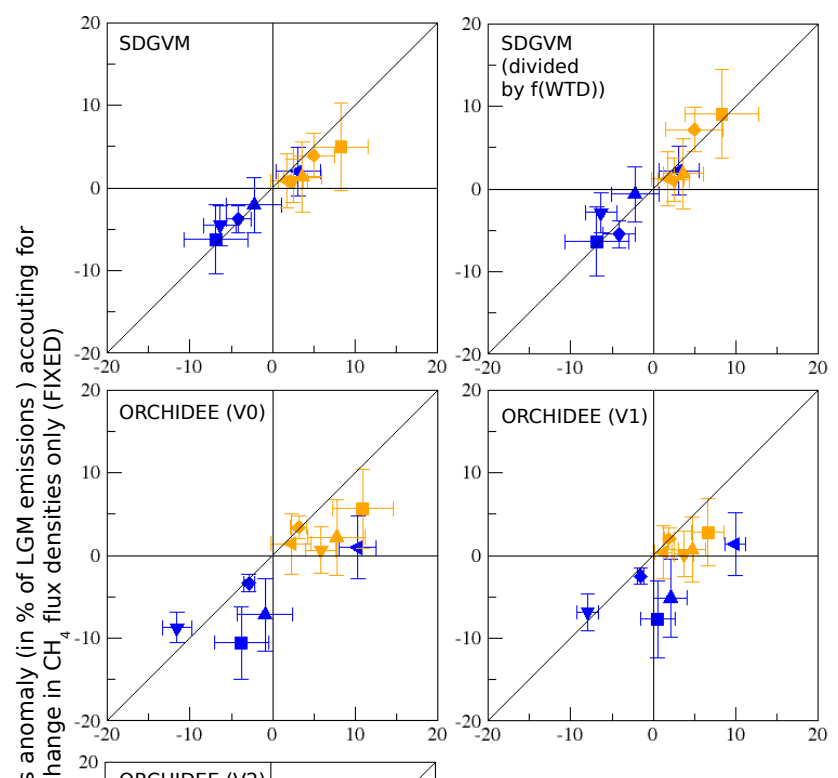

$\frac{\tilde{c}}{\frac{0}{5}}$

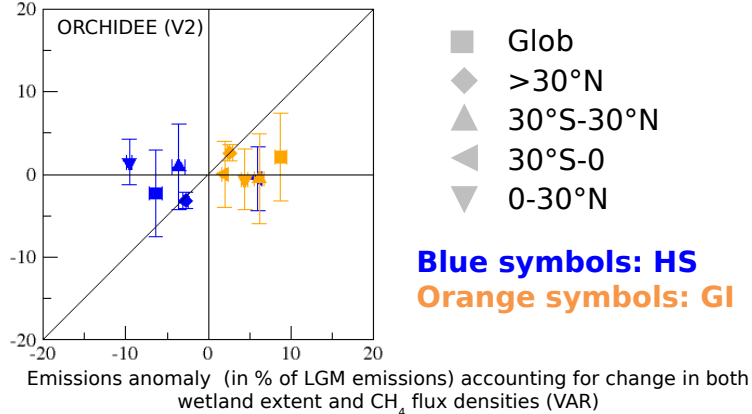

Fig. 8. Role played by the change in wetland extent in the change in emissions over the idealized D-O event for SDGVM (top panels) and the different ORCHIDEE-WET versions (bottom panels). For each latitude band, the $\mathrm{CH}_{4}$ emission annual anomalies relative to the mean global LGM emissions have been computed in two configurations (VAR and FIXED) for HS (blue) and GI (orange). The VAR anomalies ( $\mathrm{x}$-axis) are computed accounting for the variability in the wetland extents. The FIXED anomalies (y-axis) are computed after removing the wetland extent variability (i.e. the mean LGM wetland extents are prescribed during the entire D-O transient run). The errors-bars give the variability between the years of each (HS or GI) period. The SDGVM plot in the top right corner corresponds to emissions from saturated wetlands alone while the left plot represents emissions from all kinds of wetlands. The saturated wetland emissions have been approached by using the simulated $\mathrm{CH}_{4}$ flux densities divided by $f$ (WTD) (cf. the end of Sect. 2.2.2 and Eq. 3).

a given point is to the $\mathrm{x}$-axis, the higher the contribution of wetland extent in the emission anomaly. For points that fall outside of these two triangular areas, the models are showing competing influence of wetland area vs. $\mathrm{CH}_{4}$ flux densities. Namely, whilst one is acting to increase the net $\mathrm{CH}_{4}$ emissions, the other is acting to cause a reduction.

At the global scale (symbol $\square$ in Fig. 8), the role played by the change in wetland extent in the emission anomaly in SDGVM is smaller than in ORCHIDEE-V0 for both the 
warm and cold $\mathrm{D}-\mathrm{O}$ periods (the symbols are closer to the $1: 1$ line in SDGVM than in ORCHIDEE). The contribution of the changes in wetland extent is small in the two models over the boreal region $(\diamond)$ and cannot explain the difference of behaviour between SDGVM and ORCHIDEE-V0 at global scale: indeed, for each model and in the extra-tropical regions, VAR and FIXED are close. Thus, much of the difference between the two models at global scale is driven by differences in the tropical regions.

In the tropics $(\triangle)$, during HS (blue symbols), accounting for the wetland extent variability leads to a reduction of the $\mathrm{CH}_{4}$ emission anomaly from $-7.1 \pm 3.3$ (FIXED) to $-0.9 \pm 4.4 \mathrm{Tg} \mathrm{yr}^{-1}$ (VAR) in ORCHIDEE-V0 and to a change in the emissions from $-2.2 \pm 3.4$ (FIXED) to $-2.08 \pm 3.4 \mathrm{Tg} \mathrm{yr}^{-1}$ (VAR) in SDGVM. In ORCHIDEE-V0, the HS climate change (in comparison to LGM) leads to both increased emitting areas and decreased flux densities at the same time, with opposite effect on the total $\mathrm{CH}_{4}$ flux entering the atmosphere. The tropical band can be divided into two sub-regions: the $0-30^{\circ} \mathrm{N}$ and the $30^{\circ} \mathrm{S}-0$ latitudes bands. In each model, these two sub-regions have a very different behaviour regarding the $\mathrm{CH}_{4}$ emission anomalies during HS: the southern tropical band is characterized by an increase of the $\mathrm{CH}_{4}$ emissions, while the northern band sees a decrease. This is related to a southward shift in the ITCZ simulated by FAMOUS in response to the AMOC perturbation (see Hopcroft et al., 2011 for more details). SDGVM and ORCHIDEE mainly differ in terms of (i) the intensity of the emission anomaly in each sub-region and (ii) the contribution of the wetland extent in the emission anomaly of the southern tropical band. Indeed, in ORCHIDEE-V0, the HS emission anomalies reach $-11.6 \pm 1.8$ and $+10.3 \pm 3.8 \mathrm{Tg} \mathrm{yr}^{-1}$ for respectively the northern $(\nabla)$ and southern tropics $(\triangleleft)$ while they are only about of $-6.3 \pm 2.4$ and $+3.1 \pm 3.0 \mathrm{Tg} \mathrm{yr}^{-1}$ in SDGVM. In the southern tropics, the wetland extent explains around $90 \%$ of the increase in emissions in ORCHIDEEV0 and only $35 \%$ for SDGVM. These two characteristics show that, while the same HS anomaly is obtained in the two models for the entire tropical band due to a compensating effect, the underlying processes are different. Moreover, Fig. 8 also demonstrates that the $\mathrm{HS} \mathrm{CH}_{4}$ flux density anomaly in the northern tropics (blue $\nabla$ ) in ORCHIDEE-V0 is mainly due to the substrate sensitivity to change in precipitation (see the difference of the FIXED values between ORCHIDEE-V0 and ORCHIDEE-V2). In fact, the decrease in precipitation occurring in the northern tropics during HS leads to a decrease in the ORCHIDEE-simulated NPP leading to a drop of the methanogenesis substrate supply. Besides, note that accounting for the dynamic in vegetation in SDGVM during the $\mathrm{D}-\mathrm{O}$ run has a small impact on the change in productivity and could not explain differences between the two models.

Figure 8 allows us to identify which latitudinal band and process drives the main differences between SDGVM and ORCHIDEE as described in Sect. 3.2.1: the larger positive GI emission anomaly in ORCHIDEE-V0 than in
SDGVM and the positive HS emission anomaly obtained with ORCHIDEE-V1.

Regarding the $\mathrm{CH}_{4}$ emissions during the GI period, the difference between the two models described in Sect. 3.2.1 is driven by the changes in the band $0-30^{\circ} \mathrm{N}(\nabla)$. The emission anomaly in this region is about $5.3 \pm 2.9 \mathrm{Tg} \mathrm{yr}^{-1}$ where $88 \%$ can be explained by the expansion of wetland in ORCHIDEE-V0 against $2.5 \pm 2.6 \mathrm{Tg} \mathrm{yr}^{-1}$ and $63 \%$ in SDGVM.

The positive tropical anomaly obtained in ORCHIDEE$\mathrm{V} 1$ is explained by the fact that a weak change in the magnitude of the anomaly of a given tropical sub-region could strongly modify the net magnitude over the tropics as a whole, given the compensating effect described above. The Fig. 8 shows that the change in the temperature sensitivity formulation from V0 to V1 leads to a small decrease of the positive anomaly in the northern tropics (from $-8.7 \pm 1.8$ to $-6.9 \pm 1.3 \mathrm{Tg} \mathrm{yr}^{-1}$ for FIXED, i.e. a decrease of $\sim 20 \%$ ) but with no modification in the southern tropics. This small change is strong enough to disrupt the balance of the compensating effects between the two sub-tropical regions, resulting in a positive anomaly averaged over the tropics as a whole. This underlines an increased sensitivity in ORCHIDEE-WET compared to SDGVM and thus a potential larger sensitivity to smaller local changes, while this is without any substantial change at global scale in the case described above.

\section{Discussion and conclusions}

Weber et al. (2010) quantified the effect of the uncertainties linked to the LGM climate on the different factors controlling glacial changes in $\mathrm{CH}_{4}$ production by wetlands. To do so, they used different OAGCM outputs to force a unique and simple formulation of $\mathrm{CH}_{4}$ production. They found that global methane emissions from wetland were reduced by 35$42 \%$ during the LGM in comparison to the PI. Such a reduction is larger than calculated in earlier bottom-up approaches (between -16 and $-27 \%$ for Kaplan et al., 2006; Kaplan, 2002; Valdes et al., 2005) and is attributed to differences in the LGM climate simulations (PMIP2 vs. PMIP1: Braconnot et al., 2007). The LGM reduction found by Weber et al. (2010) is closer to the range of reduction found in studies based on top-down modelling (e.g. Crutzen and Brühl, 1993; Martinerie et al., 1995; Chappellaz et al., 1997) or as suggested based on atmospheric chemistry simulations (Levine et al., 2011). These studies constrained multi-dimensional chemical transport models with ice core observations and inferred the source terms, finding a reduction in the LGM wetland $\mathrm{CH}_{4}$ emissions by $40-60 \%$. The present study deals with a complementary approach to Weber et al. (2010) by using the same climate forcing as input for two different wetland $\mathrm{CH}_{4}$ emission models. We found a decrease of 46 and $67 \%$ at global scale for respectively SDGVM and the base 
ORCHIDEE-WET model (version V0). In order to better compare our simulation results with wetland $\mathrm{CH}_{4}$ emission estimates from ice-core data, we performed a last ORCHIDEE simulation, hereafter called ORCHIDEE-opt as described in Sect. 2.3. For remaining, in ORCHIDEE-opt, as in ORCHIDEE-V2, the substrate sensitivity to precipitation is removed. However, a space-constant $T_{\text {ref }}$ is used as well as a $Q_{10}$ equal to 3. The aim of ORCHIDEE-opt is to provide our best ORCHIDEE estimates of the change in wetland emissions. This version leads to a decrease in LGM as compared to PI of $36 \%$. Thus, the LGM decrease in emissions simulated by both SDGVM and the optimal ORCHIDEE version is close to the lower limit of the range given by top-down studies as discussed above.

The differences between $\mathrm{CH}_{4}$ concentrations in Greenland and Antarctica as well as the $\mathrm{CH}_{4}$ isotopic information from ice cores are additional constraints used in top-down modelling to derive the latitudinal change of (wetland) emissions between LGM and PI. Chappellaz et al. (1997) (based on the inter-hemispheric gradient) and Fischer et al. (2008) (based on isotopic information) lead to the same conclusion of a large decrease of boreal wetland emissions during LGM but do not agree on the magnitude of this decrease. The latitudinal distribution of the LGM-PI difference given by SDGVM is consistent with Chappellaz et al. (1997) ( $-57 \%$ for latitudes $>30 \circ \mathrm{N}$ ) while the simulated shut-down of boreal wetland emissions in ORCHIDEE-WET is more in agreement with Fischer et al. (2008).

New high-resolution $\mathrm{CH}_{4}$ records from Greenland and Antarctica suggest the boreal wetlands were not completely shut down (Baumgartner et al., 2012). Using the SDGVM and ORCHIDEE simulations, we computed the relative interpolar concentration difference of $\mathrm{CH}_{4}$, noted rIPD hereafter and defined by Eq. (9) of Baumgartner et al. (2012):

$\operatorname{rIPD}\left(s_{\mathrm{n}}, s_{\mathrm{s}}, \tau, t_{\mathrm{ex}}\right)=2 \cdot \frac{s_{\mathrm{n}}-s_{\mathrm{s}}}{s_{\mathrm{n}}+s_{\mathrm{s}}} \cdot \frac{1}{1+2 \frac{\tau}{t_{\mathrm{ex}}}}$

where $s_{\mathrm{n}}$ and $s_{\mathrm{s}}$ are the $\mathrm{CH}_{4}$ source for respectively the Northern $\left(0^{\circ} \mathrm{N}-90^{\circ} \mathrm{N}\right)$ and the Southern $\left(0^{\circ} \mathrm{S}-90^{\circ} \mathrm{S}\right) \mathrm{Hemi}-$ spheres, $\tau$ is the atmospheric lifetime of $\mathrm{CH}_{4}$ and $t_{\mathrm{ex}}$ is the interhemispheric mixing time. Figure 9a displays LGM rIPD using SDGVM and ORCHIDEE for different value of $\tau$ and $t_{\mathrm{ex}}$. By assuming a present-day value of $\tau(10.0 \mathrm{yr})$, as suggested by Levine et al. (2011), and $t_{\mathrm{ex}}(1.8 \mathrm{yr})$, Baumgartner et al. (2012) derived from ice cores a rIPD $=3.7 \pm 0.7 \%$ for LGM. Using the same values for $\tau$ and $t_{\mathrm{ex}}$, we find a r4IPD of $5.4 \%$ for SDGVM and between -1.0 and $1.7 \%$ for ORCHIDEE-V0, V1 and V2. ORCHIDEE-opt gives a rIPD $=3.5 \%$, very close to the value found by Baumgartner et al. (2012). However, the value of rIPD is very sensitive to a small difference in $s_{\mathrm{n}}$ and $s_{\mathrm{s}}$. This is underlined in Fig. 9a by the error bars that give the range of rIPD for SDGVM and ORCHIDEE if $25 \%$ of the closest grid cells of Southern Hemisphere to the Equator are accounted for in $s_{\mathrm{n}}$ instead of
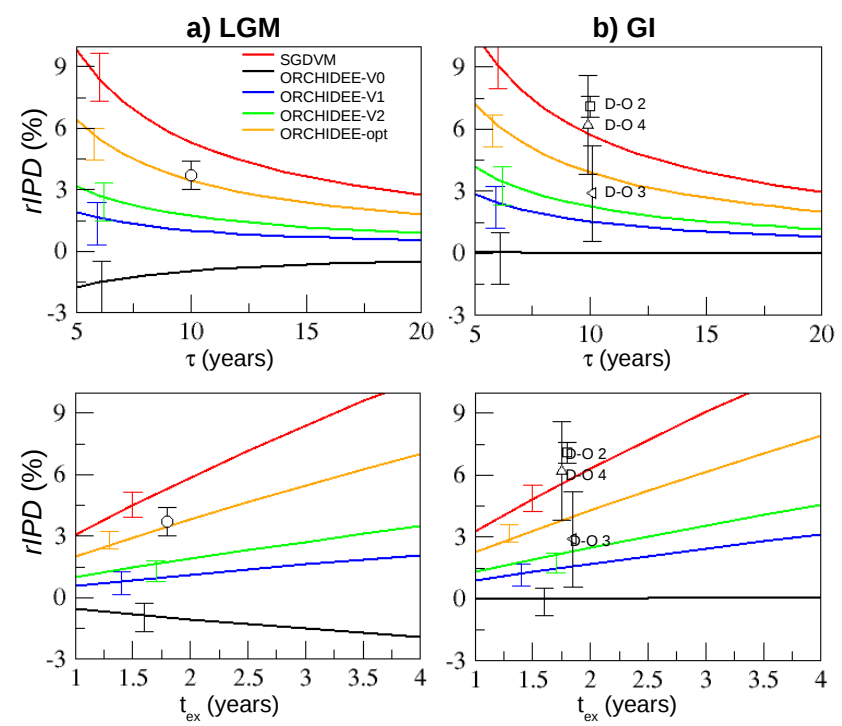

Fig. 9. Relative interpolar concentration difference of $\mathrm{CH}_{4}$ (rIPD, in \%) computed for LGM (a) and over the idealized D-O (b) event using SDGVM (red curve) and the different ORCHIDEE versions. Both sensitivity to the $\mathrm{CH}_{4}$ atmospheric lifetime ( $\tau$, top panels) and the interhemispheric mixing time ( $t_{\mathrm{ex}}$, bottom panels) are given. While one parameter is varied, the other is set to its present-day value ( $\tau=10.1 \mathrm{yr}$ and $t_{\mathrm{ex}}=2 \mathrm{yr}$ ). Values of rIPD derived from ice cores by Baumgartner et al. (2012) assuming present-day value for $\tau$ and $t_{\mathrm{ex}}$ are plotted with errors-bars relative to uncertainty in measurements. The error bars for models give the range of rIPD if $25 \%$ of the closest grid cells of Southern Hemisphere to the Equator are accounted for in northern hemispheric sources $\left(s_{\mathrm{n}}\right)$ instead of into the southern hemispheric ones $\left(s_{\mathrm{S}}\right)$ (or vice-versa).

into $s_{\mathrm{s}}$ (or vice-versa). The rIPD value given by Eq. (4) has to be taken with caution, because only two source regions (corresponding to the two hemispheres) are considered. The two-box split does not therefore account for the basic atmospheric circulation patterns (e.g. Hadley cells), nor does it allow separation of emissions from boreal wetland and northern low latitudes. However, it has the advantage of allowing a simple analytic computation of the rIPD (Baumgartner et al., 2012). Given the uncertainties linked to the latitudinal change of emissions, it is not possible to unambiguously discriminate between SDGVM and ORCHIDEE-opt. However, the comparison between the "observed" rIPD and the rIPD computed using the different ORCHIDEE versions suggests that the modification of the methanogenesis substrate sensitivity to the precipitation in the ORCHIDEE model improves the performance of the model in comparison with the icecore data (see below).

The intercomparison between two independent models, which account for different processes, could help us to improve our understanding of the potential drivers of the wetland $\mathrm{CH}_{4}$ emission change during glacial-interglacial transition. While temperature seems to play a small role in the LGM decrease of wetland $\mathrm{CH}_{4}$ emissions in Weber et 
al. (2010), we have shown that modifying the $Q_{10}$ parameterization of the methanogenesis sensitivity is sufficient to reconcile the global LGM-PI change between the two models studied here. The $\mathrm{CH}_{4}$ production sensitivity to temperature is highly uncertain at different spatial scales with large effects on the global distribution of wetland emissions (see e.g. Riley et al., 2011, for the effect on both sites and global scale under current climate). It is however likely that a $Q_{10}=1.5$ as used in SDGVM is too low. Bringing together the different constraints (i.e. measurements at sites, the distribution of wetland emissions at global scale against topdown estimates, ice-core measurements of LGM-PI change in $\left[\mathrm{CH}_{4}\right]$ ) could help us to reduce the range of plausible $Q_{10}$ values. A further issue is the baseline temperature used in the $Q_{10}$ formulation $\left(T_{\text {ref }}\right)$ and its potential variability in space and time as a way to represent microbial space-scale processes of adaptation (Riley et al., 2011; Z. M. Subin, personal communication, 2011). Additional sensitivity tests with a time variable $T_{\text {ref }}$ as in Ringeval et al. (2011) could be performed to evaluate the effect on the simulated change in $\mathrm{CH}_{4}$ emissions between LGM and PI. However, there is still a debate about how influential a microbial community temperature adaptation would be for soil organic matter mineralization. For instance, Rousk et al. (2012) showed that a change in the microbial community (i.e. an adaptation) would be minor as compared to the direct effect of temperature on microbial activity and the indirect effect on the quality of the soil organic matter. Also, discontinuity in the mineralization sensitivity to temperature around $0^{\circ} \mathrm{C}$ (Koven et al., 2011) could have a strong effect on the LGM-PI change in emissions and calls for additional tests.

An interesting feature of this work is that the modification of the $Q_{10}$ formulation of the sensitivity temperature (from ORCHIDEE-V0 to ORCHIDEE-V1) does not reconcile the latitudinal distribution of the LGM-PI change between the ORCHIDEE-WET and SDGVM. Other processes are also relatively simply represented in the models (e.g. the constant oxidation related to the plant-transport of $\mathrm{CH}_{4}$ in ORCHIDEE) and could have an effect on the simulated LGM-PI change in wetland $\mathrm{CH}_{4}$ emissions.

In the present study and contrary to Weber et al. (2010), the wetland extent seems to play a small role in explaining the LGM-PI change in emissions. This is particularly true in ORCHIDEE-WET in the boreal regions where the $\mathrm{CH}_{4}$ flux densities collapse and drive the major part of the reduction in emission. This pattern is explained by a large decrease in the ORCHIDEE-simulated methanogenesis substrate. The difference of modelled substrate supply between SDGVM and ORCHIDEE-WET underlies why a modification of the $Q_{10}$ value cannot reconcile the latitudinal distribution of the LGM-PI of the two models. This emphasizes the key role of the substrate supply as suggested by Kaplan (2002). However, the driver of the NPP decrease is still not clear: while Kaplan (2002) explains the low LGM NPP is driven by the reduction in atmospheric $\mathrm{CO}_{2}$ concentration, we highlight the impact of soil freezing on vegetation productivity as a potentially important influence. It is also likely the surface hydrology of models during LGM needs to be improved. For example, consideration of permafrost covered areas, glacial runoff from the Andes and Asian mountains and different hydrological drainage systems may all be important.

This intercomparison discloses some limitations of each model and allows us to suggest different ways of improvement. Regarding ORCHIDEE, we require an improvement to the subgrid computation of the methanogenesis substrate. A limitation is linked to the fact a subgrid computation is performed for the hydrology (through TOPMODEL) but not for the carbon cycle. In this way, the mean carbon over the grid cell is used as proxy of the wetland substrate and this makes the modelled substrate more sensitive to change in precipitation since pre-existing wetland fractions might in reality see less relative change in the soil moisture. This inconsistency between the treatments of hydrology/carbon cycle could be resolved by introducing new wetland plant functional types, which would be restricted to fractional grid cells diagnosed as wetlands using TOPMODEL. Furthermore, we suggest replacing the $Q_{10}$ formulation by an Arrhenius-type equation where the effective activation energy for respiration varies inversely with temperature. In SDGVM, we suggest modifying the contribution of the wetland extent versus $\mathrm{CH}_{4}$ flux densities under PI conditions (see Fig. 4) to more closely satisfy available observations. This could be done by scaling the $\mathrm{CH}_{4}$ flux densities to measurement from sites, and the global wetland extent, e.g. against the value given by Papa et al. (2010) dataset. While the present study does not underline a large effect of the imbalance between the two emission components on the simulated change in emissions in comparison to ORCHIDEE, it may not be the case under other climates. Also, we suggest increasing the value of the $Q_{10}$ for the methanogenesis parameterization. Finally, introducing a simple parameterization of freeze/thaw of soil water could help to more accurately model changes in the methanogenesis substrate availability.

Over the idealized D-O events, the magnitude of the change in wetland $\mathrm{CH}_{4}$ emissions simulated by two models at global scale is very similar (GI-HS: 14.2 and $14.8 \%$ relative to LGM emissions respectively for SDGVM and ORCHIDEE-V0). Our best estimate using ORCHIDEE leads to a slightly higher change of $18 \%$ (cf. dash orange curve in Fig. 7, top panel). As described by Hopcroft et al. (2011), the SDGVM-simulated changes in wetland $\mathrm{CH}_{4}$ emissions during the idealized $\mathrm{D}-\mathrm{O}$ event are too low to explain the measured change in $\left[\mathrm{CH}_{4}\right]$. In the present study, the same conclusion is also reached with ORCHIDEE-WET: the likely impact of the simulated emissions on the $\left[\mathrm{CH}_{4}\right]$ will not differ between the two models. And without any change in the $\mathrm{CH}_{4}$ lifetime, the amplitude of the change in global emissions simulated by the two models $\left(\sim 15 \mathrm{Tg} \mathrm{yr}^{-1}\right)$ is much lower than that required $\left(\sim 60 \mathrm{Tg} \mathrm{yr}^{-1}\right)$ to match a change of $200 \mathrm{ppb}$ in the $\left[\mathrm{CH}_{4}\right]$, the upper range of observed D-O events (see 
Fig. 9 of Hopcroft et al., 2011). However the contribution of wetlands to D-O events is still open for debate. For instance, Melton et al. (2012b) estimated that tropical wetlands would increase a maximum of $14 \mathrm{Tg} \mathrm{yr}^{-1}$ for a global increase of $64 \mathrm{Tg} \mathrm{yr}^{-1}$ in case of the Younger Dryas termination, though this is not usually considered a Dansgaard-Oeschger event.

Our simulations point to two features that could lead to increased $\mathrm{D}-\mathrm{O}$ forced change in emissions simulated by ORCHIDEE-WET in both the tropics and extra tropics. Firstly, in ORCHIDEE-WET, the LGM boreal emissions are nearly zero. Thus the global $\mathrm{D}-\mathrm{O}$ changes are almost exclusively explained by the tropics. However, because the $Q_{10}$ of the methanogenesis is larger in ORCHIDEE-WET than in SDGVM, larger boreal emissions at the beginning of the $\mathrm{D}-\mathrm{O}$ simulations will likely lead to increase the global change during the different phases of the $\mathrm{D}-\mathrm{O}$ events. Additionally, we have shown that the local (half tropical band scale) anomalies are much larger in ORCHIDEE-WET than in SDGVM (between twice and three times larger). A weak change in the magnitude of the anomaly of a given tropical sub-region could strongly modify the magnitude of the overall total tropical anomaly given the compensating effect described in Sect. 3.2.2. This underlines an increased sensitivity in ORCHIDEE-WET compared with SDGVM and thus a potential larger sensitivity to local changes. Sensitivity FAMOUS simulations with different background conditions (i.e. modifying orbital insolation, global ice volume, greenhouse gases level) have been performed in Hopcroft et al. (2011) and could be used to test these two assumptions relative to the boreal and tropical regions. Relatively little information about the latitudinal change in wetland $\mathrm{CH}_{4}$ emissions during D-O events has been derived from the ice core measurements up to now. Bock et al. (2010) used combined information from the inter-hemispheric gradient and $\mathrm{CH}_{4}$ isotopes to derive source contributions and latitudinal change in emissions of each source between different time periods of the D-O 8 ( $\sim 37 \mathrm{kyr} B \mathrm{P})$. According to their modelling approach, the high-latitude wetland emissions strengthened from $\sim 5$ to $\sim 32 \mathrm{Tg} \mathrm{yr}^{-1}$ from stadial to early-interstadial conditions, whereas tropical wetland emissions strengthened only moderately (from $\sim 84$ to $\sim 118 \mathrm{Tg} \mathrm{yr}^{-1}$ ). While the change in boreal emissions between HS and GI is larger in SDGVM than in ORCHIDEE (respectively 9.7 and $5.4 \mathrm{Tg} \mathrm{yr}^{-1}$ ), both models simulate a lower variation of boreal emissions than inferred by Bock et al. (2010). Baumgartner et al. (2012) computed also rIPD for different $\mathrm{D}-\mathrm{O}$ events and found values of $7.1 \pm 0.5,2.9 \pm 2.3$ and $6.2 \pm 2.4 \%$ for respectively the D-O 2, 3 and 4 using present-day values for $\tau$ and $t_{\mathrm{ex}}$. Levine et al. (2012) suggested that the lifetime stayed relatively constant during D$\mathrm{O}$ events, because the effects of both warming and changes in volatile organic compound emission were found to produce effects of approximately equal but opposite sign in their atmospheric chemistry simulations. We compute also rIPD during our idealized GI for SDGVM and the different
ORCHIDEE versions (Fig. 9b). Both SDGVM and our best ORCHIDEE estimation are close to the value found by Baumgartner et al. (2012) for D-O 2 and 4. This could suggest that, while the wetland $\mathrm{CH}_{4}$ emission sensitivity to the $\mathrm{D}-\mathrm{O}$ climate seems to be under-estimated in the models, this under-estimation is homogeneously shared between the Northern and Southern Hemispheres. However, it should also be noted that a 2-box model of the global $\mathrm{CH}_{4}$ sources and atmospheric mixing may not discriminate adequately between the tropical and boreal source regions. This limitation will need to be addressed in future work.

While potential increases in ORCHIDEE-WET simulated wetland $\mathrm{CH}_{4}$ emissions seem to be possible, the results are very similar for the two models over the idealized D-O event. Moreover, contrary to what has been found for the LGM, the ORCHIDEE-simulated change in emissions during DO shows a relatively low sensitivity to the different parameterizations. This hints at either missing processes related to wetlands, a change in other sources/in the $\mathrm{OH}$ sink or alternative $\mathrm{D}-\mathrm{O}$ mechanism of $\mathrm{D}-\mathrm{O}$ climate change. The two latter have been discussed in Hopcroft et al. (2011), and we focus here on the first point. The present study as Singarayer et al. (2011) and Hopcroft et al. (2011) underlines the key role of the tropics in controlling the variability in wetland $\mathrm{CH}_{4}$ emissions over paleo-timescales. However, many processes important for tropical wetlands are not accounted for in the current wetland $\mathrm{CH}_{4}$ emission models, which have been developed primarily for the conditions encountered in the most extensively investigated mid-to-northern latitudes. In particular, explicit representation of floodplain hydrology processes in connection with river routing will be required in addition to wetlands saturated from below as represented by ORCHIDEE-WET and SDGVM. These processes are particularly relevant in regions such as the Amazon Basin (Miguez-Macho and Fan, 2012). As suggested by Bock et al. (2010) and discussed above, a change in boreal wetland $\mathrm{CH}_{4}$ emissions appears to be required during some D-O events. In these regions, slow processes such as the exposure of land surface as the ice sheet retreated are clearly not capable of producing such fast variations (Wolff and Spahni, 2007). $\mathrm{CH}_{4}$ emissions associated with permafrost destabilization need to be incorporated into paleo-modelling studies such as the one performed here. 
Appendix A
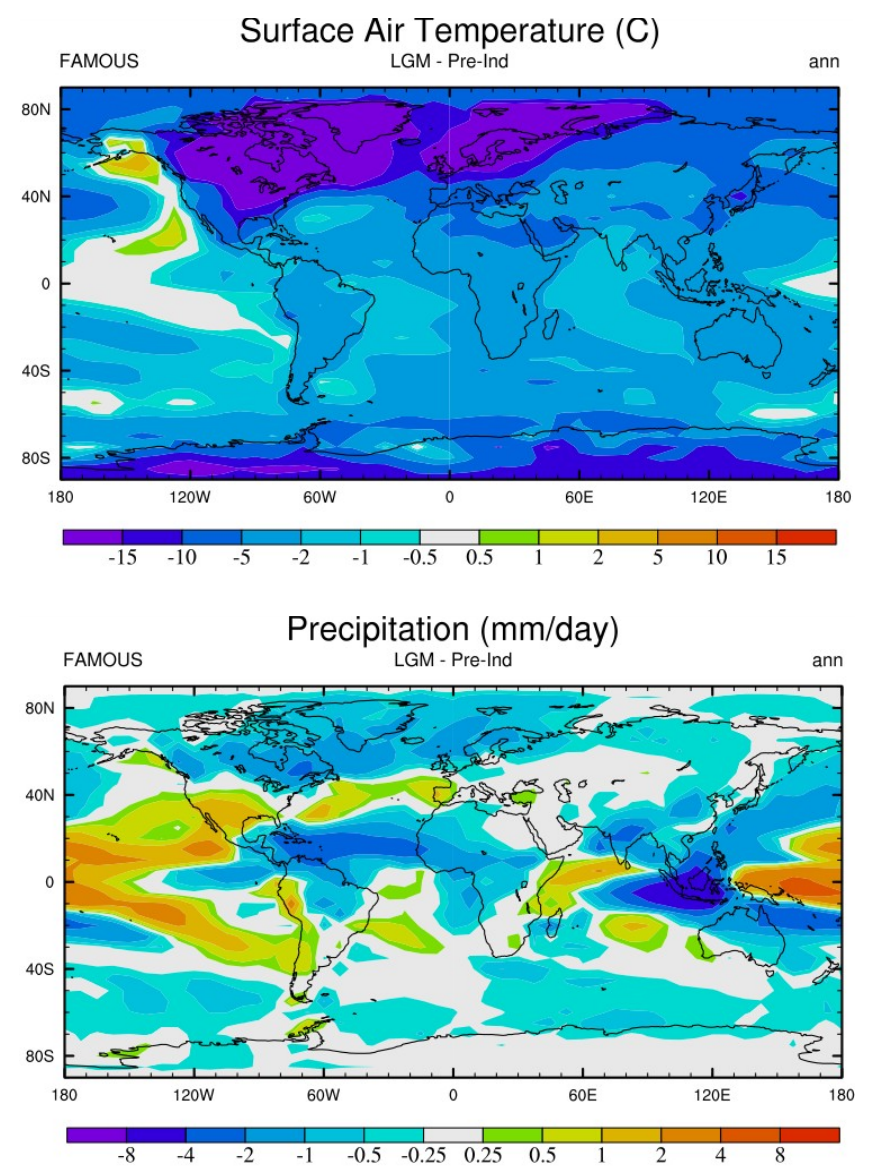

Fig. A1. LGM climate fields simulated by FAMOUS: surface temperature $\left({ }^{\circ} \mathrm{C}\right.$, top panel) and precipitation $\left(\mathrm{mm} \mathrm{day}^{-1}\right.$, bottom panel).
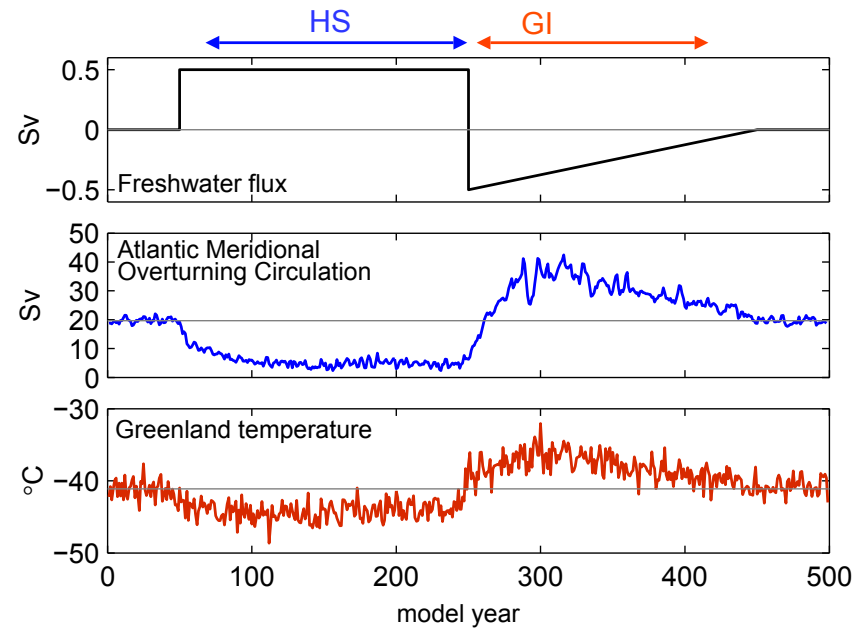

Fig. A2. Applied freshwater forcing to FAMOUS from LGM conditions to perturb the AMOC and mimic D-O events (top panel). Corresponding evolution of the AMOC (middle panel) and Greenland temperature (bottom panel) simulated by FAMOUS. 
a) Prigent et al. at $1^{\circ} \mathrm{deg}$ resolution

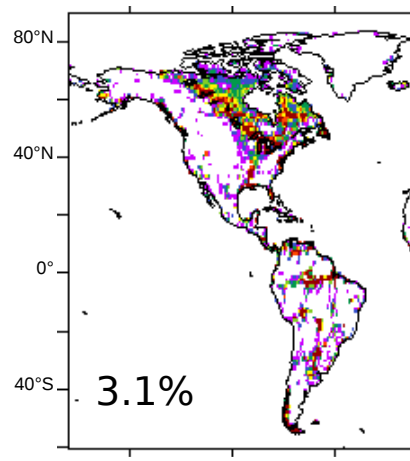

c) Prigent et al. at FAMOUS resolution: regrid of a) b) ORC-TOPMODEL: 1deg resolution simulation
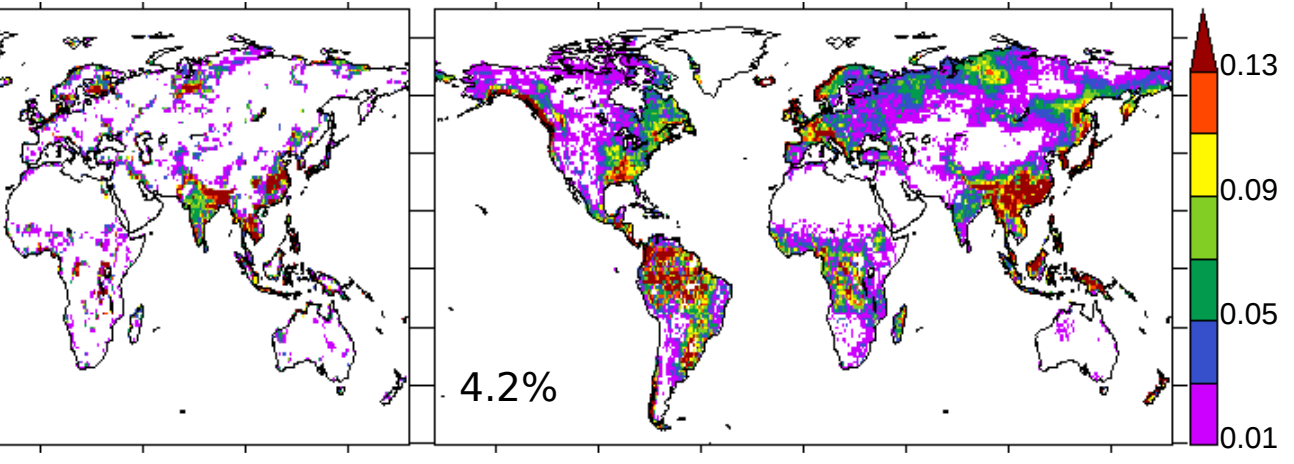

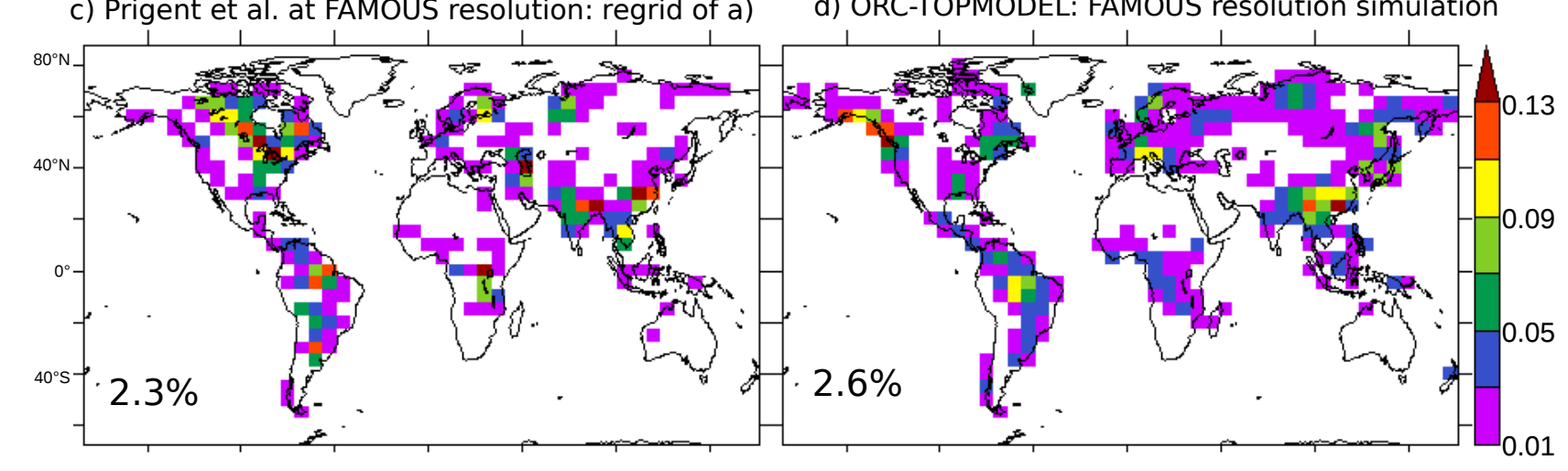

d) ORC-TOPMODEL: FAMOUS resolution simulation

e) Regrid of b)

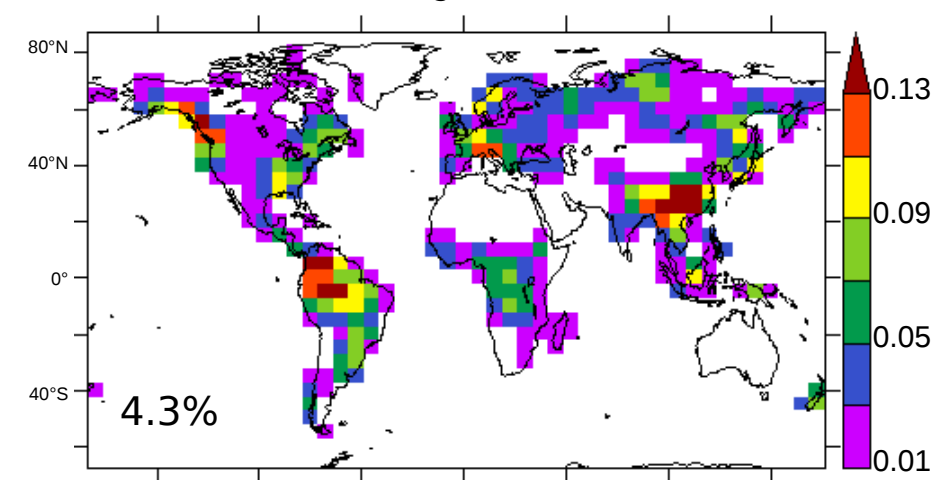

Fig. A3. Effect of the change in resolution on the Prigent et al. (2007) dataset (inundated areas) (left panels) and on the saturated wetland extents simulated by ORCHIDEE-TOPMODEL (right panels) (expressed in mean annual fraction). The number given in the left bottom corner of each panel corresponds to the global coverage of the wetland extent in $\%$. 
a) PI potential vegetation distribution

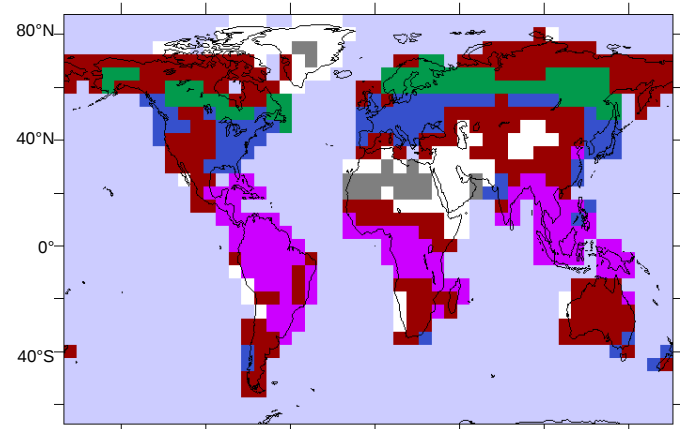

c) PI simulated vegetation distribution

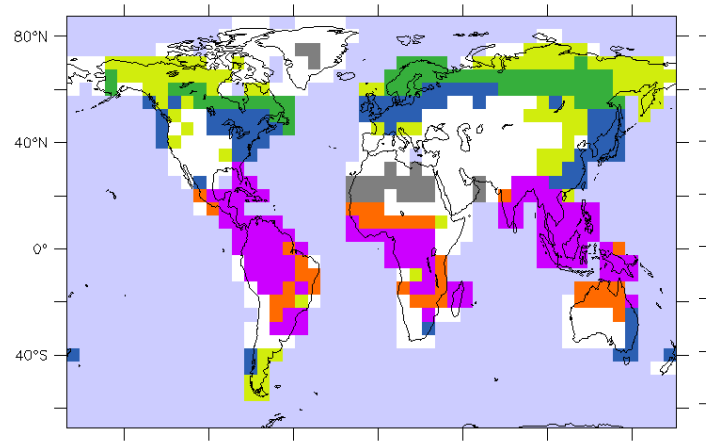

d) LGM simulated vegetation distribution

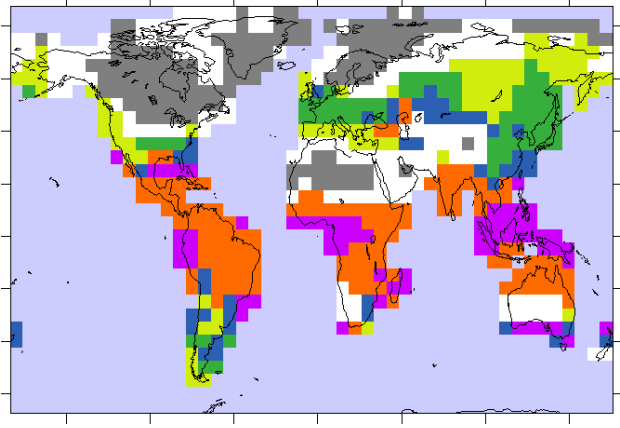

$\mathrm{C} 3 / \mathrm{C} 4$

grasses

Boreal trees

Temperate

trees

Tropical

trees

e) LGM - PI change in NPP for boreal trees

f) LGM - PI change in NPP C3 grasses

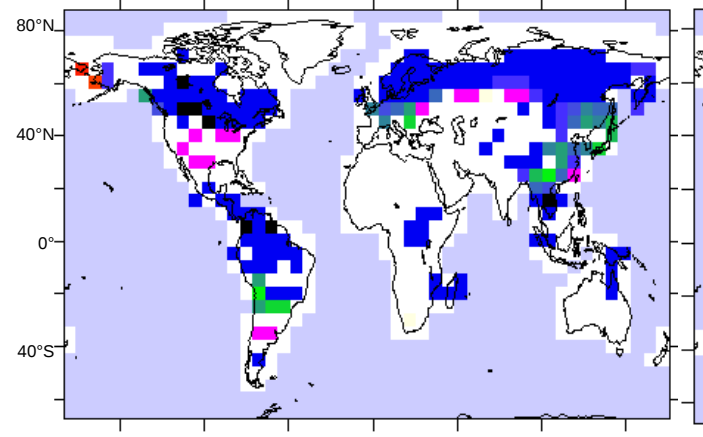

LGM - PI change in JJA humidity stress for C3 grass

g) For ORCHIDEE-VO

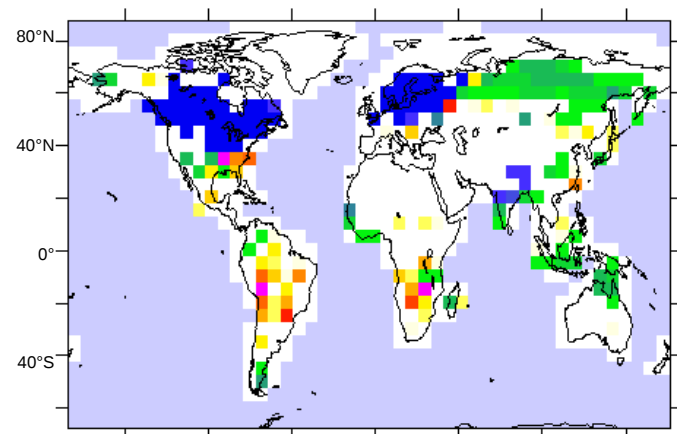

h) For ORCHIDEE-V2

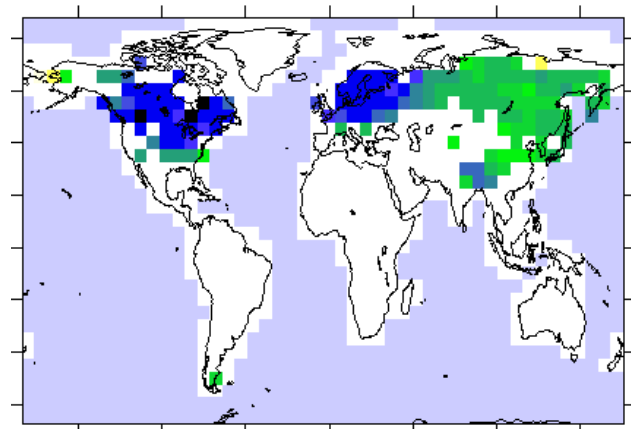

C4 grass

C3 grass

Boreal trees

Temperate

trees

Tropical

trees

Fig. A4. For ORCHIDEE: (a)-(b): prescribed maximum potential PFT coverage: distribution of the main supra-PFT classes for PI (a) and LGM (b) used as input of ORCHIDEE. (c)-(d): Simulated annual maximum PFT coverage: distribution of the main supra-PFT classes for PI (c) and LGM (d). The annual maximum PFT coverage is dependent on NPP. (e)-(f): LGM-PI change in NPP for boreal trees (c) and for C3-grass (d) (in percent of its PI value). (g)-(h): LGM-PI change in JJA humidity stress for C3 grass vegetation for ORCHIDEE-V0 (e) and ORCHIDEE-V2 (f) (in percent of its PI value). 
Acknowledgements. We would like to thank David Beerling for original development of the SDGVM- $\mathrm{CH}_{4}$ model. We would like also to warmly thank Marie-Noelle Woillez for providing the LGM vegetation map for ORCHIDEE and for her help in the review process. We also thank Angela V. Gallego-Sala and Pierre Friedlingstein for informative and helpful discussions during the elaboration of this work. Finally, we would like to thank Joe Melton for his constructive comments on the manuscript.

Edited by: V. Rath

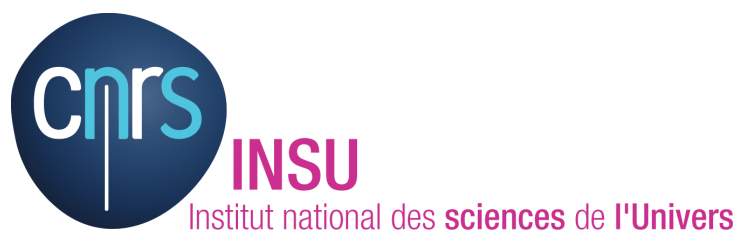

The publication of this article is financed by CNRS-INSU.

\section{References}

Bartlein, P. J., Harrison, S. P., Brewer, S., Connor, S., Davis, B. A. S., Gajewski, K., Guiot, J., Harrison-Prentice, T. I., Henderson, A., Peyron, O., Prentice, I. C., Scholze, M., Seppa, H., Shuman, B., Sugita, S. Thompson, R. S., Viau, A. E., Williams, J., and $\mathrm{Wu}, \mathrm{H}$.: Pollen-based continental climate reconstructions at 6 and 21 ka: a global synthesis, Clim. Dynam., 37, 775-802, doi:10.1007/s00382-010-0904-1, 2010.

Baumgartner, M., Schilt, A., Eicher, O., Schmitt, J., Schwander, J., Spahni, R., Fischer, H., and Stocker, T. F.: High-resolution interpolar difference of atmospheric methane around the Last Glacial Maximum, Biogeosciences, 9, 3961-3977, doi:10.5194/bg-93961-2012, 2012.

Bock, M., Schmitt, J., Möller, L., Spahni, R., Blunier, T., and Fischer, H.: Hydrogen isotopes preclude marine hydrate $\mathrm{CH}_{4}$ emissions at the onset of Dansgaard-Oeschger events, Science, 328, 1686-1689, doi:10.1126/science.1187651, 2010.

Bohn, T. J., Lettenmaier, D. P., Sathulur, K., Bowling, L. C., Podest, E., McDonald, K. C., and Friborg, T.: Methane emissions from western Siberian wetlands: heterogeneity and sensitivity to climate change, Environ. Res. Lett., 2, 045015, doi:10.1088/17489326/2/4/045015, 2007.

Bousquet, P., Ringeval, B., Pison, I., Dlugokencky, E. J., Brunke, E.G., Carouge, C., Chevallier, F., Fortems-Cheiney, A., Frankenberg, C., Hauglustaine, D. A., Krummel, P. B., Langenfelds, R. L., Ramonet, M., Schmidt, M., Steele, L. P., Szopa, S., Yver, C., Viovy, N., and Ciais, P.: Source attribution of the changes in atmospheric methane for 2006-2008, Atmos. Chem. Phys., 11, 3689-3700, doi:10.5194/acp-11-3689-2011, 2011.

Braconnot, P., Otto-Bliesner, B., Harrison, S., Joussaume, S., Peterchmitt, J.-Y., Abe-Ouchi, A., Crucifix, M., Driesschaert, E., Fichefet, Th., Hewitt, C. D., Kageyama, M., Kitoh, A., Laîné, A., Loutre, M.-F., Marti, O., Merkel, U., Ramstein, G., Valdes, P., Weber, S. L., Yu, Y., and Zhao, Y.: Results of PMIP2 coupled simulations of the Mid-Holocene and Last Glacial Maximum Part 1: experiments and large-scale features, Clim. Past, 3, 261277, doi:10.5194/cp-3-261-2007, 2007.
Cao, M., Marshall, S., and Gregson, K.: Global carbon exchange and methane emission from natural wetlands: Application of a process-based model, J. Geophys. Res., 101, 14399-14414, 1996.

Chappellaz, J., Bluniert, T., Raynaud, D., Barnola, J. M., Schwander, J., and Stauffer, B.: Synchronous changes in atmospheric $\mathrm{CH}_{4}$ and Greenland climate between 40 and $8 \mathrm{kyr}$ BP, Nature, 366, 443-445, 1993.

Chappellaz, J., Blunier, T., Kints, S., Dällenbach, A., Barnola, M., Schwander, J., Raynaud, D., Stauffer, B., Dallenbach, A., and Barnola, J.: Changes in the atmospheric $\mathrm{CH}_{4}$ gradient between Greenland and Antarctica during the Holocene, J. Geophys. Res., 102, 15987-15997, doi:0148-0227/97/97JD-0101709.00, 1997.

Crutzen, P. J. and Brühl, C.: A model study of atmospheric temperatures and the concentrations of ozone, hydroxyl, and some other photochemically active gases during the glacial, the preindustrial Holocene and the present, Geophys. Res. Lett., 20, 1047-1050, 1993.

Dallenbach, A., Blunier, T., Fluckiger, J., Stauffer, B., Chappellaz, J., and Raynaud, D.: Changes in the atmospheric $\mathrm{CH}_{4}$ gradient between Greenland and Antarctica during the Last Glacial and the transition to the Holocene, Geophys. Res. Lett., 27, 10051008, doi:10.1029/1999GL010873, 2000.

Decharme, B. and Douville, H.: Global validation of the ISBA subgrid hydrology, Clim. Dynam., 29, 21-37, doi:10.1007/s00382006-0216-7, 2007.

Fischer, H., Behrens, M., Bock, M., Richter, U., Schmitt, J., Loulergue, L., Chappellaz, J., Spahni, R., Blunier, T., Leuenberger, M., and Stocker, T. F.: Changing boreal methane sources and constant biomass burning during the last termination, Nature, 452, 864-867, doi:10.1038/nature06825, 2008.

Fung, I., John, J., Lerner, J., Matthews, E., Prather, M., Steele, L. P., and Fraser, P. J.: Three-Dimensional Model Synthesis of the Global Methane Cycle, J. Geophys. Res., 96, 13033-13065, doi:10.1029/91JD01247, 1991.

Hopcroft, P. O., Valdes, P. J., and Beerling, D. J.: Simulating idealized Dansgaard-Oeschger events and their potential impacts on the global methane cycle, Quaternary Sci. Rev., 30, 3258-3268, doi:10.1016/j.quascirev.2011.08.012, 2011.

Kageyama, M., Mignot, J., Swingedouw, D., Marzin, C., Alkama, R., and Marti, O.: Glacial climate sensitivity to different states of the Atlantic Meridional Overturning Circulation: results from the IPSL model, Clim. Past, 5, 551-570, doi:10.5194/cp-5-5512009, 2009.

Kaplan, J. O.: Wetlands at the Last Glacial Maximum: Distribution and methane emissions, Geophys. Res. Lett., 29, 3-6, 2002.

Kaplan, J. O., Folberth, G., and Hauglustaine, D. A.: Role of methane and biogenic volatile organic compound sources in late glacial and Holocene fluctuations of atmospheric methane concentrations, Global Biogeochem. Cy., 20, GB2016, doi:10.1029/2005GB002590, 2006.

Klein Goldewijk, K., Bouwman, A. F., and van Drecht, G.: Mapping contemporary global cropland and grassland distributions on a 5 by 5 minute resolution, J. Land Use Sci., 2, 167-190, 2007.

Koven, C. D., Ringeval, B., Friedlingstein, P., Ciais, P., Cadule, P., Khvorostyanov, D., Krinner, G., and Tarnocai, C.: Permafrost carbon-climate feedbacks accelerate global warming, P. Natl. Acad. Sci. USA, 108, 14769-14774, doi:10.1073/pnas.1103910108, 2011. 
Krinner, G., Viovy, N., de Noblet-Ducoudré, N., Ogée, J., Polcher, J., Friedlingstein, P., Ciais, P., Sitch, S., and Prentice, I. C.: A dynamic global vegetation model for studies of the coupled atmosphere-biosphere system, Global Biogeochem. Cy., 19, GB1015, doi:10.1029/2003GB002199, 2005.

Levine, J. G., Wolf, E. W., Jones, A. E., Sime, L. C., Valdes, P. J., Archibald, A. T., Carver, G. D., Warwick, N. J., and Pyle, J. A.: Reconciling the changes in atmospheric methane sources and sinks between the Last Glacial Maximum and the pre-industrial era, Geophys. Res. Lett., 38, L23804, doi:10.1029/2011GL049545, 2011.

Levine, J. G., Wolff, E. W., Hopcroft, P. O., Valdes, P. J.: Controls on the tropospheric oxidizing capacity during an idealized Dansgaard-Oeschger event, and their implications for the rapid rises in atmospheric methane during the last glacial period, Geophys. Res. Lett., 39, L12805, doi:10.1029/2012GL051866, 2012.

Loulergue, L., Schilt, A., Spahni, R., Masson-Delmotte, V., Blunier, T., Lemieux, B., Barnola, J.-M., Raynaud, D., Stocker, T. F., and Chappellaz, J.: Orbital and millennial-scale features of atmospheric $\mathrm{CH}_{4}$ over the past 800,000 years, Nature, 453, 383386, doi:10.1038/nature06950, 2008.

Martinerie, P., Brasseur, G. P., and Granier, C.: The chemical composition of ancient atmospheres: A model study constrained by ice core data, J. Geophys. Res., 100, 14291-14304, 1995.

Melton, J. R., Wania, R., Hodson, E. L., Poulter, B., Ringeval, B., Spahni, R., Bohn, T., Avis, C. A., Beerling, D. J., Chen, G., Eliseev, A. V., Denisov, S. N., Hopcroft, P. O., Lettenmaier, D. P., Riley, W. J., Singarayer, J. S., Subin, Z. M., Tian, H., Zürcher, S., Brovkin, V., van Bodegom, P. M., Kleinen, T., Yu, Z. C., and Kaplan, J. O.: Present state of global wetland extent and wetland methane modelling: conclusions from a model intercomparison project (WETCHIMP), Biogeosciences Discuss., 9, 1157711654, doi:10.5194/bgd-9-11577-2012, 2012a.

Melton, J. R., Schaefer, H., and Whiticar, M. J.: Enrichment in ${ }^{13} \mathrm{C}$ of atmospheric $\mathrm{CH}_{4}$ during the Younger Dryas termination, Clim. Past, 8, 1177-1197, doi:10.5194/cp-8-1177-2012, 2012b.

Miguez-Macho, G. and Fan, Y.: The role of groundwater in the Amazon water cycle: 1. Influence on seasonal streamflow, flooding and wetlands, J. Geophys. Res., 117, 1-30, doi:10.1029/2012JD017539, 2012.

Papa, F., Prigent, C., Aires, F., Jimenez, C., Rossow, W. B., and Matthews, E.: Interannual variability of surface water extent at the global scale, 1993-2004, J. Geophys. Res., 115, 1-17, doi:10.1029/2009JD012674, 2010.

Peltier, W. R.: Global Glacial Isostasy and the Surface Ot the IceAge Earth: The Ice-5g(Vm2) Model and Grace, Ann. Rev. Earth Planet. Sci., 32, 111-149, 2004.

Petrescu, A. M. R., van Beek, L. P. H., van Huissteden, J., Prigent, C., Sachs, T., Corradi, C. A. R., Parmentier, F. J. W., and Dolman, A. J.: Modeling regional to global $\mathrm{CH}_{4}$ emissions of boreal and arctic wetlands, Global Biogeochem. Cy., 24, GB4009, doi:10.1029/2009GB003610, 2010.

Prigent, C., Papa, F., Aires, F., Rossow, W. B., and Matthews, E.: Global inundation dynamics inferred from multiple satellite observations, 1993-2000, J. Geophys. Res., 112, 1-13, doi:10.1029/2006JD007847, 2007.
Riley, W. J., Subin, Z. M., Lawrence, D. M., Swenson, S. C., Torn, M. S., Meng, L., Mahowald, N. M., and Hess, P.: Barriers to predicting changes in global terrestrial methane fluxes: analyses using CLM4Me, a methane biogeochemistry model integrated in CESM, Biogeosciences, 8, 1925-1953, doi:10.5194/bg-8-19252011, 2011.

Ringeval, B., de Noblet-Ducoudré, N., Ciais, P., Bousquet, P., Prigent, C., Papa, F., and Rossow, W. B.: An attempt to quantify the impact of changes in wetland extent on methane emissions on the seasonal and interannual time scales, Global Biogeochem. Cy., 24, 1-12, doi:10.1029/2008GB003354, 2010.

Ringeval, B., Friedlingstein, P., Koven, C., Ciais, P., de NobletDucoudré, N., Decharme, B., and Cadule, P.: Climate- $\mathrm{CH}_{4}$ feedback from wetlands and its interaction with the climate$\mathrm{CO}_{2}$ feedback, Biogeosciences, 8, 2137-2157, doi:10.5194/bg8-2137-2011, 2011.

Ringeval, B., Decharme, B., Piao, S. L., Ciais, P., Papa, F., de Noblet-Ducoudré, N., Prigent, C., Friedlingstein, P., Gouttevin, I., Koven, C., and Ducharne, A.: Modelling sub-grid wetland in the ORCHIDEE global land surface model: evaluation against river discharges and remotely sensed data, Geosci. Model Dev., 5, 941-962, doi:10.5194/gmd-5-941-2012, 2012.

Rousk, J., Frey, S. R., and Baath, E.: Temperature adaptation of bacterial communities in experimentally warmed forest soils, Global Change Biol., 18, 3252-3258, doi:10.1111/j.13652486.2012.02764.x, 2012.

Saulnier, G.-M. and Datin, R.: Analytical solution to a bias in the TOPMODEL framework balance, Hydrol. Process., 18, 11951218, doi:10.1002/hyp.1346, 2004.

Singarayer, J. S. and Valdes, P. J.: High-latitude climate sensitivity to ice-sheet forcing over the last $120 \mathrm{kyr}$, Quaternary Sci. Rev., 29, 43-55, doi:10.1016/j.quascirev.2009.10.011, 2010.

Singarayer, J. S., Valdes, P. J., Friedlingstein, P., Nelson, S., and Beerling, D. J.: Late Holocene methane rise caused by orbitally controlled increase in tropical sources, Nature, 470, 8285, doi:10.1038/nature09739, 2011.

Smith, R. S., Gregory, J. M., and Osprey, A.: A description of the FAMOUS (version XDBUA) climate model and control run, Geosci. Model Dev., 1, 53-68, doi:10.5194/gmd-1-53-2008, 2008.

Spahni, R., Wania, R., Neef, L., van Weele, M., Pison, I., Bousquet, P., Frankenberg, C., Foster, P. N., Joos, F., Prentice, I. C., and van Velthoven, P.: Constraining global methane emissions and uptake by ecosystems, Biogeosciences, 8, 1643-1665, doi:10.5194/bg8-1643-2011, 2011.

Valdes, P. J., Beerling, D. J., and Johnson, C. E.: The ice age methane budget, Geophys. Res. Lett., 32, 2-5, doi:10.1029/2004GL021004, 2005.

Walter, P., Heimann, M., and Matthews, E.: Modeling modern methane emissions from natural wetlands 1 . Model description and results, J. Geophys. Res., 106, 34189-34206, doi:10.1029/2001JD900164, 2001.

Wania, R., Ross, I., and Prentice, I. C.: Implementation and evaluation of a new methane model within a dynamic global vegetation model: LPJ-WHyMe v1.3.1, Geosci. Model Dev., 3, 565-584, doi:10.5194/gmd-3-565-2010, 2010. 
Weber, S. L., Drury, A. J., Toonen, W. H. J., and van Weele, M.: Wetland methane emissions during the Last Glacial Maximum estimated from PMIP2 simulations: Climate, vegetation, and geographic controls, J. Geophys. Res., 115, 1-13, doi:10.1029/2009JD012110, 2010.

Woillez, M.-N., Kageyama, M., Krinner, G., de Noblet-Ducoudré, N., Viovy, N., and Mancip, M.: Impact of $\mathrm{CO}_{2}$ and climate on the Last Glacial Maximum vegetation: results from the ORCHIDEE/IPSL models, Clim. Past, 7, 557-577, doi:10.5194/cp7-557-2011, 2011.
Wolff, E. W. and Spahni, R.: Methane and nitrous oxide in the ice core record, Philos. T. Roy. Soc. A, 365, 1775-1792, doi:10.1098/rsta.2007.2044, 2007.

Wolff, E. W., Chappellaz, J., Blunier, T., Rasmussen, S. O., and Svensson, A.: Millennial-scale variability during the last glacial: the ice core record. Quaternary Sci. Rev., 29, 2828-2838, 2010. 